SB 995

.C46

Copy 2 


$$
\widetilde{\sigma}
$$








\title{
THE
}

\section{ECONOMIC VALUE}

\section{OF BIRDS TO THE STATE}

\author{
BX
}

\section{FRANH M. CHAPMAN}

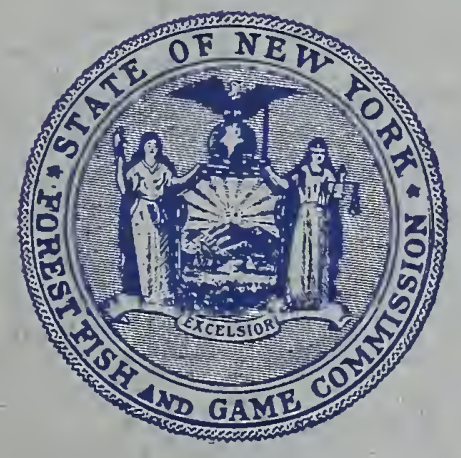

ALBANY。

J. B. LYON COMPANY, PRINTERS 1903 

Compliments of

WILLIAM F. FOX.

Supt. State Forests. 

State of New Tork

Forest, Fish and Game Commission

\title{
The Economic Uatae of Birds to the State
}

\author{
BW \\ Frank M. Chapman \\ Associate Curator of Ilammotogy and ornithology in the American \\ Nuseum of Naturat History
}

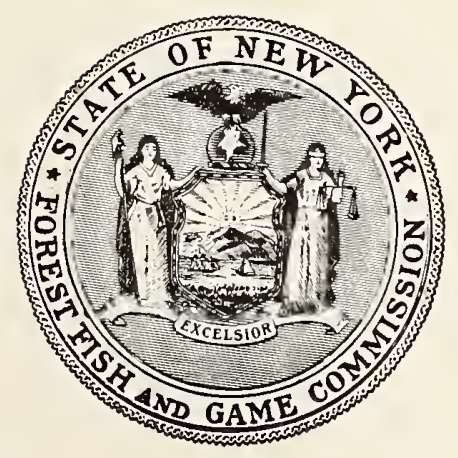

ALBANY

J. B. LYON COMPANY, PRINTERS

1903 


$$
0_{\infty}^{\infty} e^{\infty}
$$

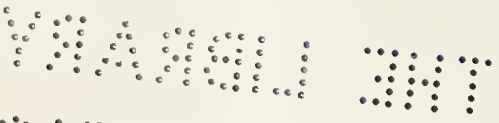

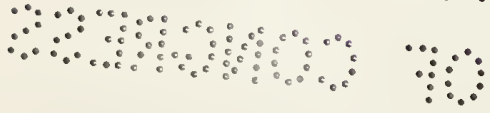




\section{Contents.}

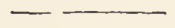

PAGE.

The Bird and the State, - $\quad$ - $\quad$ - $\quad$ - $\quad$ - $\quad$ - $\quad$ - 5

What The Bird Does for the State, - $\quad$ - $\quad$ - $\quad$ - $\quad$ - $\quad$ - $\quad$ - 6

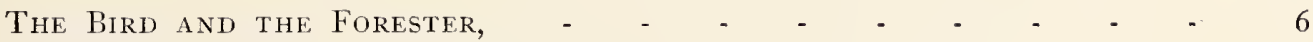

The Bird and the Fruit-Grower, - $\quad$ - $\quad$ - $\quad-\quad-\quad-\quad$ - $\quad$ io

The Bird and the Farmer, - $\quad$ - $\quad$ - $\quad$ - $\quad$ - $\quad$ - $\quad$ - $\quad$ - $\quad$ I5

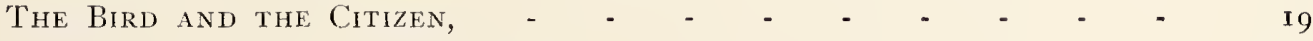

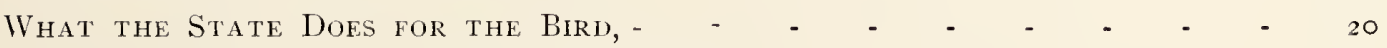

What the State Should Do for the Bird, - $\quad$ - $\quad$ - $\quad$ - $\quad$ - $\quad$ - $\quad$ - 2 I

The Facts in the Case, - $\quad$ - $\quad$ - $\quad$ - $\quad$ - $\quad-\quad$ - $\quad$ - 22

How a Bird's Value to Man is Ascertained, - - $\quad$ - $\quad-\quad-\quad 23$

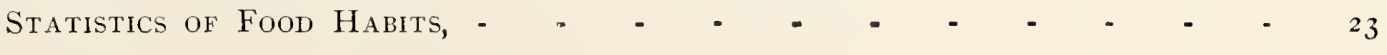





\title{
Economic Uatae of Birds to the State.
}

\author{
BY FRANK M. CHAPMAN \\ ASSOCIATE CURATOR OF MAMMOLOGY AND ORNITHOLOGY IN THE \\ AMERICAN MUSEUM OF NATURAL HISTORY.
}

The Bird and the state.

$\mathrm{T}$

$\mathrm{HE}$ bird is the property of the State. From this fundamental conception of the bird's legal status there can be no logical ground for dissent. If a certain species of bird is conclusively proven to be injurious to the agricultural or other interests of the State, no one would deny the State's right to destroy that species. If, on the contrary, a species is shown to be beneficial, then the State has an equal right to protect it. Indeed, we may go further and say it is not only the right, but the duty of the State to give to its birds the treatment they deserve. Here is the great Commonwealth of New York with agricultural and forestry industries which annually yield products valued at $\$ 266,000,000$. In the closest relation to the welfare of these industries stands a group of animals represented by some 350 species and millions of individuals. Obviously, then, it is the first duty of the State to learn definitely in what way or ways the presence of these incalculably abundant creatures affects its crops and forests.

If they are harmful how are they to be destroyed? If they are valuable how are they to be preserved? In short, the State should take all necessary steps to appraise its vast possessions in bird-life.

The government at Washington realizes the importance of this subject and in r886 it established, in the Department of Agriculture, a Division of Economic Ornithology and Mammology, with the object of learning accurately the economic relations of birds and mammals to man. Illinois, Wisconsin, Nebraska, Pennsylvania, Massachusetts and New Hampshire, among the States, have made investigations with the same end in view. Now the South is awakening to the vital importance of this practical side of natural history research. At the Annual Session of the Texas Farmers' Congress, held at College Station, Texas. July I7, 1902, Professor H. P. Attwater, a prominent ornithologist in the State, was invited to make an address on "The Relation of Birds to the Farmer." In commenting on this address The State, 
a newspaper of Meridan, Miss., says: "Bird protection is going to be made an economic issue in every Southern State before many days, and the army of sentimental advocates will be reinforced by the utilitarians, who, while caring nothing for the beauty of the feathered songster or the music he makes, are very much alive to his usefulness in exterminating insects that kill crops, and are determined to stay the hand of the snarer and wanton bird-killer before it is too late and the insects have taken possession of the land. $* *$ Wherever common sense prevails this cause will find advocates, and The State would like to see Bird Protection made an issue in Mississippi politics."

No " issue," however, can be successfully promoted unless the facts involved rest on the firm, incontrovertible foundation established by exact research. The Forest, Fish and Game Commission of New York State, in calling the attention of the citizens of the State to the economic importance of birds, desires to present, therefore, the results of the investigations of economic ornithologists into the food habits of our birds. But before giving in detail the studies of these specialists it will be well to outline in a general way how birds may be valuable or injurious to man.

\section{What the Bird Does for the State.}

Birds are of value to the State chiefly through the services they render in (I) eating harmful insects, their eggs and larvæ; (2) in eating the seeds of noxious weeds; (3) in devouring field mice and other small mammals which injure crops; (4) in acting as scavengers. The appended outline of the bird's relation to the forester, fruit-grower, farmer, and citizen will enable us to appreciate its economic importance.

\section{The BIRD AND THE Forester.}

The agriculturist, in producing an artificial condition in the plant world, creates also an unnatural state of affairs among the insects that find a new food in the outcome of his husbandry and among the birds that prey upon these insects. But between birds and forests there exist what may be termed primeval, economic relations. Certain forest trees have their natural insect foes to which they furnish food and shelter; and these insects, in turn, have their natural enemies among the birds to which the trees also give a home. Here, then, we have an undisturbed set of economic relations:(I) the tree; (2) the insect which lives in the tree, preys upon it, and may assist in the fertilization of its blossoms; (3) the bird which also finds a home in the tree and, feeding upon insects, prevents their undue increase. Hence, it follows that the existence of each one of these forms of life is dependent 
upon the existence of the other. Birds are not only essential to the welfare of the tree, but the tree is necessary to the life of the bird. Consequently, there has been established what is termed "a balance of life" wherein there is the most delicate adjustment between the tree, the insect, the bird and the sum total of the conditions which go to make up their environment. The more trees, the greater the number of insects, and, hence, an increase not only in food supply for the birds, but an increase in the number of nesting-sites.

Destroy the trees and the insect finds new food in the crops of the farmer, but the birds, although food is still abundant, lose their home when the tree falls, and, lacking the nesting-sites and protection from their enemies once found in its spreading branches, they soon perish.

What we may call artificial forest conditions are to be found in parks, squares, village streets, and in our gardens. Here forest trees may find a suitable soil, but birds are often less abundant in such localities than in the forest, and consequently the trees growing in them are notably less healthy than forest trees. It is in these semi-domesticated trees that a scourge of injurious insects most often occurs, occasionally to be followed by a marked increase of their bird enemies, which are attracted by the unusual abundance of food. Such an instance is recorded in BirdLorc for October, I899, by Caroline G. Soule, who writes:

"Last year, at Brandon, Vermont, the tent-caterpillars were so abundant as to be a serious injury and annoyance. They lay in close rows, making wide bands on the tree trunks. They spun down from the upper branches and fell upon the unfortunate passers-by. They crawled through the grass in such numbers that it seemed to move in a mass as one looked down upon it. Under these circumstances, birds might be expected to do strange things - and they did.

"The pair of Downy Woodpeckers which lived near us were frequently seen on the ground picking up the crawling tent-caterpillars. They seemed to prefer taking them from the ground to taking them from the trees, though there were more on the tree-trunks than on the ground even. And the Woodpeckers seemed to have no difficulty in moving on the ground, though they moved more slowly than when dodging around a tree.

"Two mountain-ash trees on the place were infested by borers, though only slightly and only near the ground, and at the foot of one of these trees the Downy Woodpeckers made many a stand, while they probed the borer-holes with their bills.

"The Cuckoos came boldly into the village and fed and fed, flying about quite openly. The Nuthatches flew to a band of caterpillars on a tree-trunk, and were so 
busy and absorbed in devouring the crawlers that I could put my hand on them before they started to fly, and then they merely flew to another tree close by, and attacked another mass of caterpillars.

"Blackbirds waddled over the grass by the sides of the streets picking up the crawlers, and even a Woodcock spent several hours in the garden and on the lawn, apparently feasting on tent-caterpillars, but I could not get near enough to be sure.

"The Vireos -- White-eyed, Red-eyed and Warbling - the Cat-birds, Cedar-birds, and Rose-breasted Grosbeaks did good service to the trees and human beings, but the most evident destruction was done by the Chipping Sparrows when the moths emerged late in the summer. The moths were very abundant after four o'clock in the afternoon, flying about the trees to lay their eggs, and then the Chippies became fly-catchers for the time, and flew straight, turned, twisted, dodged, and tumbled 'head over heels and heels over head' in the air, just as the course of the hunted moth made necessary. A quick snap of the beak, and four brownish wings would float down like snowflakes, and their numbers on the walks, roads and grass showed how many thousands of moths were slain. In spite of the unwonted exercise the Chippies waxed fat, but not as aldermanic as the Robins, which, earlier, gorged themselves on the caterpillars until, as one observer said, "their little red fronts actually trailed on the ground.",

The extent to which trees are subject to attack and their consequent need of insect destroyers may be more clearly understood if we consider for a moment the life of a tree in connection with the insects that prey upon it. Let us take, for example, the oaks of the genus Quercus.* At the very beginning, before the acorn has germinated, it may be entered by a grub of the nut weevil (Balaninus) which destroys it, and the more or less empty shell becomes the abiding place of the larva of the acorn moth. Should, however, the acorn be permitted to grow, the roots of the young tree may be attacked by the white grubs of root-boring beetles. Escaping these, the oak carpenter worm (Prionorystus) lays its eggs in cracks and crevices in the bark. On hatching, the worm or borer "perforates a hole the size of a halfinch auger, or large enough to admit the little finger, and requiring three or four years for the bark to close together over it. This hole, running inward to the heart of the tree, and admitting water thereto from every shower that passes, causes a decay in the wood to commence, and the tree never regains its previous soundness." (Fitch.)

Other borers (Buprestide) feed upon the bark, eating the soft inner layer and

\footnotetext{
* See Packard, Forest Insects, Fifth Report U. S. Entomological Commission.
} 
the sap, over twenty species of borers and miners being known to infest the trunk of the oak. The limbs and twigs are affected by the larve of certain beetles (Cerambycida) which act as girdlers or pruners, sometimes severing limbs ten feet in length and over an inch in diameter. (Fitch.) The weevils also bore into the twigs, making an excavation in which the eggs are laid, and the seventeen-year locust stings the branches, making perforations from one to two feet long for the receipt of the eggs.

The limbs and twigs are also affected by tree hoppers (Membracide) and oak blights (Aphidida), which puncture them and feed upon their juices, exhausting the sap. Some ten species of scale insects, or plant-lice, are known to infest oaks, and over a hundred different species of gallflies are parasitic upon them.

Oak buds are eaten by the larva of certain noctuid moths, and oak leaves are injured by caterpillars, basket worms, skippers, miners, weevils, phylloxeras, galls and plant-lice of nearly one hundred and fifty species.

Altogether over 500 species of insects are known to prey upon the oak, and it is consequently obvious that if they were not in turn preyed upon, oak trees could not exist. But, thanks to the services of birds, as well as to predaceous and parasitic insects, the insectivorous foes of the oak are so held in check that, as a rule, their depredations are not attended by serious results. Remove these checks, however, and we may expect an immediate and disastrous increase in the enemies of the oak which they so successfully combat.

Without here attempting to go into detail we may at least mention one or two instances illustrative of the value of birds to trees. Weevils, borers, caterpillars, scale insects and plant-lice are all devoured by birds, but it is in eating the eggs of the enemies of the trees that birds perform a service of inestimable value. Prof. C. M. Weed, of the New Hampshire College of Agriculture, in studying the winter food of the Chickadee, has found that it feeds largely on the eggs of plant-lice. Thus the stomach of a specimen taken December 9, in a mixed growth of pines, maple, willow, and birches, was found to contain 429 eggs of plant-lice, together with insects of several species. The stomach of another Chickadee taken February 26, in a growth of pines and birches, contained 454 eggs of Aphides, an equal percentage (44) of what seemed to be dried castings from the old nests of tent-caterpillars, spiders' eggs, and eggs of the canker-worm.

Additional statistics of the forest haunting birds' food are given under the proper head, but we should call especial attention here to the great value to trees of our Cuckoos in devouring caterpillars. Over 48 per cent of the food of Cuckoos has been found by Professor Beal, of the U.S. Department of Agriculture, to con- 
sist of caterpillars, the stomach of a single individual containing the remains of $2 \mathrm{I} 7$ web-worms well known to be one of the most destructive forms of insect life to trees. These are only two illustrations, among the hundreds which might be cited, of the service rendered by the birds to our forest.

Birds are of value to the forest, however, not only as the destroyers of their insect foes, but the birds with the squirrels, help plant the forest by distributing seeds. The seeds which are encased in a pulpy covering, those of the berry or fruitbearing trees, are voided unharmed by the birds often at a point far distant from the parent tree, the bird thus acting as their distributor. Acorns, beech-nuts, and chestnuts are frequently dropped or hidden by birds, and the seeds of pines are released and scattered by the birds that seek them in their cones. In short, we believe it can be clearly demonstrated that if we should lose our birds we should also lose our forests.

ThE BIRD AND THE FRUIT-gROWER.

In considering the relations of birds to the fruit-grower we encounter an artificial set of conditions which renders an attempt to determine the birds' position exceedingly difficult. In growing certain fruits, for example pears and apples, a natural forest environment is closely approximated, the trees furnishing a home for the birds which are not attracted by their fruit but by the insects that prey upon them. With smaller fruits (e.g., berries), however, exactly the reverse occurs, that is, they furnish food but no shelter for the birds which, during the periods of fruitage, tempted by an abundant food supply, abandon their usual fare and may prove positively harmful. Catbirds and Robins in the cherry trees and strawberry beds, and Orioles in the vineyards undeniabiy cause considerable loss to the fruit-grower.

There are two sides to this question, however, and no species of birds should be condemned for the depredations of one month until we known its value during the remaining eleven. The bird, we repeat, is the property of the State, not of the individual. The State seeks to secure the greatest good for the greatest number of its citizens, and if it can be shown that a Robin or Catbird, in spite of its fruit-eating proclivities, is, on the whole, far more valuable than harmful, then assuredly he should not be sacrificed.

It does not necessarily follow that the fruit-grower's' complaints are to be ignored. Their cause should be thoroughly investigated by qualified experts under the supervision of the Forest, Fish and Game Commission in order that no hasty or undesirable measures may be taken.

In the spring of 1900 the peach trees of the Hudson Valley were visited by large 
numbers of birds which destroyed quantities of young peaches. The peach-growers took the law into their own hands and killed these birds by the thousand. Subsequently, and perhaps as a result, an unsuccessful attempt was made so to amend the Game Law of the State of New York that a fruit-grower might kill any bird which he believed to be injurious to his crops.

The birds in this case were Red Crossbills and White-winged Crossbills, which, as a rule, feed exclusively on the seeds of coniferous trees. Owing to a failure in their food supply for the season of r899-1900 they came south in exceptional numbers and were common throughout the winter in places where they are rarely seen. The writer, in twenty years' experience, has not witnessed such an invasion of these boreal birds, and it is probable that they may not be as numerous again for twenty years more. While, on this occasion, Crossbills undoubtedly did much damage to the peach crop, the facts in the case render it improbable that they may again be destructive to peaches in the present generation. In their own range, under normal conditions, Crossbills are of value to forestry as distributors of the seeds of conifers, and it obviously would be a poor economist who would condemn a species for a few weeks wrong-doing when its previous record showed it to be uniformly beneficial. The death penalty is an extreme measure to inflict on birds when the verdict is based on evidence from only one side. The planting of early Russian mulberries, which birds are more fond of than strawberries and cherries, is one way of protecting these fruits without harming the birds. Again, nets and various devices, including the discharge of firearms loaded only with powder, may prove as effective as the actual killing of the bird.

With pear and apple orchards, as has been said, this question of fruit-eating does not exist, and the service rendered them by birds has been most convincingly demonstrated by Mr. E. H. Forbush, from whose observations, published in the Massachusetts Crop Report for July, 1895 , the following extract is taken. Selecting an old, neglected orchard, he made an especial effort to attract certain birds to it with the most interesting results. Mr. Forbush writes:

" The orchard itself is a typical old orchard, such as is often found on small farms. It has suffered greatly from neglect. Two-thirds of the original trees have died or are in the last stages of dissolution. This is largely the result of neglect and improper pruning. Dead limbs and hollows in the trees have offered nesting places for such birds as the Wren, Woodpecker and Bluebird.

“For three years, from I 891 to 1893 , inclusive, the trees were trimmed and cared for. They were sprayed or banded to protect them from canker worms, and the 'nests' of the tent-caterpillar (Clissocampa americana) were removed. The result 
was a scanty yield of apples from most of the trees. One or two bore quite plentifully.

"In order to observe the effect of the feeding of birds in the orchard no care was taken in 1894 to protect the trees. During that year the tent-caterpillars were very numerous in the vicinity, and it became evident also that a great increase in the number of canker worms was taking place in the neighborhood. Although these insects made considerable inroads upon the trees, they did not seriously injure the foliage anywhere except in one or two instances. No attempt had been made previous to I 895 to foster or encourage the birds in the neighborhood, except that a few nesting boxes were put up in I894, which were occupied in one case by a family of Wrens, and in another by the English or House Sparrow. We were careful, however, to destroy the nests of the House Sparrow.

"In the fall of I 894 it was noticed that immense numbers of the wingless females of the fall canker worm (Anisopteryx pometaria) were ascending nearly all the trees and depositing their eggs; also, that the eggs of tent-caterpillar moths were numerous on the twigs, promising a plentiful supply for 1895 .

“ Hiaving allowed the insects one year to increase unmolested by man, we began in the winter of $1894-95$ to encourage the presence of birds in the orchard.

"In I 894 a small tree in the center of the orchard had been inclosed by a high board fence. The tree thus inclosed was used as an cut-door experiment station for observations on the breeding and habits of the gypsy moth. During the winter of I 894-95, Mr. C. E. Baily made frequent visits to this tree to ascertain whether or not the birds were destroying the eggs of the gypsy moth. Incidentally, Mr. Baily observed many interesting things in connection with the feeding of birds on the eggs, larva and pupæ of insects which winter on the trees, and I am greatly indebted to him for many interesting notes on the feeding of birds in this orchard. $\mathrm{He}$ is a careful, conscientious observer, and is intimately acquainted with most of our native land birds.

"Hunters and trappers are aware that many species of winter birds, such as Titmice, Woodpeckers, Crows, Jays and Nuthatches, are attracted by a skinned carcass suspended from a limb, and will remain in the vicinity until all the bones are picked clean, or until, with the approach of spring, insect food becomes more accessible.

"Believing from my own observations that the Chickadees (Pamus atricapillus) were feeding on the eggs of the fall canker worm, I asked Mr. Baily to attract the birds, if possible, to the orchard, by suspending pieces of meat, bone, suet, from the trees. These food materials are good for birds at times when the trees are covered with snow or ice, and when, lacking such nourishment, they might starve. Although 
birds will frequently visit bait provided for them and in time will eat a considerable portion of the meat, they do not depend entirely on this aliment, but spend the greater portion of their time in searching for cggs and insects in the immediate vicinity.

"Finding a plentiful supply of food, the Chickadees remained about the orchard most of the winter, except for a week or two, when the meat gave out, but they were lured back again later by a fresh supply which was placed in the trees. Not only were the Chickadees attracted to the orchard in large numbers, but other birds came also. A pair of Downy Woodpeckers (Dryobates pubescens) and two pairs of Nuthatches (Sitta carolinensis) were frequent visitors, and a few Brown Creepers (Certhia ancricana) came occasionally. All these paid frequent visits to the meat and suet, and also thoroughly inspected the trees in search of insect food. They made excursions also to the trees in the neighborhood, but the greater portion of their attention was confined to the orchard in which the bait was suspended. As they became more accustomed to Mr. Baily's presence, they grew quite tame and could be viewed at a distance of a few feet. Indeed the Chickadees frequently alighted on his person and occasionally took food from his hand. He was thus enabled to determine accurately (without killing them) what they were feeding upon, and was soon convinced that they were destroying the eggs of the canker worm moth in large numbers, as well as the hibernating larva and pupæ of other insects injurious to trees."

Investigation showed that this was the case, the stomachs of four birds containing no less than I,028 canker-worms' eggs, while one Chickadee had eaten 4 I canker-worm moths. As the moths at this season contained, on the average, 185 eggs each, it is probable that this single bird destroyed over 7,ooo canker-worms' eggs in a day. Details of this interesting experiment are given in the statistical portion of this report, here we may turn at once to Mr. Forbush's results. In the spring "it soon became evident," he continues, that the neighboring orchards which had not been under the birds' care, "would be entirely stripped of their leaves, while the old orchard retained its full foliage. Thus it was seen that the trees to which the Chickadees had been lured during the winter had been so well protected that the summer birds were able to destroy the few remaining larvæ, while the trees at a distance from these contained so many larva that the birds were not numerous enough to dispose of them or to make any effective reduction in their numbers. . . .

"During the month of May an attempt was made to render the place as attractive to the birds as possible. The undergrowth, which previous to 1894 had been trimmed out, was afterward allowed to grow, and in I $\$ 95$ several low thickets had 
been formed; the mulberry trees were stimulated by judicious trimming, and bore a considerable crop of early fruit which ripened in advance of the cherries, and served to attract them to the vicinity of the orchard. Ten nesting boxes were put up for the IVrens and Blue-birds; but as the Blue-birds were very rare this season none came to the orchard. Two families of IVrens, however, were reared in the boxes in place of one family last year. Nesting materials - strings, hair and straw - were hung in the trees and scattered about. Several marauding cats were killed, and an attempt was made to keep nest-hunting boys away from the neighborhood as much as possible. Thirty-six nests of birds were discovered in the neighborhood, as follows :

“Three red-eyed Vireos, ten Robins, four Baltimore Orioles, three Cuckoos, five Chipping Sparrows, three Least Flycatchers, two Redstarts, two Yellow Warblers, two Chickadees, two House IVrens.

"Of these all but three were destroyed, probably by boys, the nests being torn down and the eggs missing. The three which escaped destruction were two wrens' nests, which had been built in boxes upon buildings, and a robin's nest in a maple tree within ten feet of a chamber window. This wholesale destruction of nests discouraged several pairs of birds, and they disappeared from the neighborhood. Those remaining built new nests, and after a second or third attempt a few succeeded in rearing young. One nest of Orioles escaped the general destruction, and the birds were busy for a long time carrying canker-worms to their young. One of them was noticed to take eleven canker-worms in its beak at one time and fly with them to the nest. The Vireos, IVarblers, Chickadees, Cuckoos, Orioles and Chipping Sparrows were particularly active in catching canker-worms, and the English Sparrow killed them in considerable numbers.

"If the thirty-six pairs of birds whose nests were found had succeeded in raising their young it is probable that they would have disposed of most of the cankerworms in the neighborhood. Five thousand of these larvæ are sufficient to strip a large apple tree. One hundred and eight would have been reared had each pair of birds raised three. According to Professor Aughey's experience sixty insects per day as food for each bird, both young and old, would be a very low estimate. Suppose each of these one hundred and eight birds had received its sixty insects per day, there would have been 6,480 caterpillars destroyed daily. The destruction of this number of caterpillars would be enough to save the foliage and fruitage of one apple tree. In thirty days the foliage of thirty apple trees could have been saved, or I94,400 canker-worms destroyed. This does not include what the old birds themselves would have eaten." 
Mr. Forbush concludes: "At the present time, July 23, I895, the trees in the orchard appeared to be in good condition. They have not suffered from the slight pruning of their foliage which was effected by the few caterpillars and canker-worms which survived. The fruit is well set and it here remains to be seen whether the birds will have any considerable effect in preventing the ravages of the coddling moth. No other orchard in the neighborhood will produce any fruit this season, with one exception."

Not the least valuable part of Mr. Forbush's report is his description of the methods employed to make his orchard attractive to birds. We shall return to this later, but such vitally important steps as the leaving of some undergrowth and killing of cats cannot be urged too often.

\section{THE BIRD AND THE FARMER.}

In the growing of field and garden crops, of grains and vegetables, the farmer produces a more artificial state of affairs than that which is occasioned by the fruitgrower, or, at least, the orchardist. The nature of his crops, their frequent tilling, and often early reaping, all combine to make them afford poor nesting-sites, even for such birds as would be likely to select them. To most insectivorous birds, however, areas devoted to farming purposes do not offer suitable nesting places, and it follows, therefore, that where the farmer most needs the services of insect-eating birds there these birds are deprived of surroundings in which they might find shelter and rear their young.

We shall later see how, to some extent, these conditions may be remedied. In the meantime we may inquire more closely into the relations of the bird and the farmer. Birds are of value on the farm (I) as insect-eaters, (2) as seed-eaters, (3) as mouse or rodent-eaters. Birds are injurious on the farm when they attack the crops, such damage being essentially restricted to corn, rye, and other grains. As in other cases, it is our object to learn what species are beneficial and what injurious, and to determine whether the harm done by certain species at certain seasons is outweighed by the good they do at other seasons.

The value of birds as insect-eaters is so obvious it will be unnecessary to dwell here on this phase of their relations to agriculture. One instance, however, may be cited in which birds preserved a crop through the destruction of its insect foes. It came under the observation of so excellent an authority as Prof. F. E. L. Beal, of the U. S. Department of Agriculture, from whose address before the New Jersey State Horticultural Society I quote as follows: "Field observation and stomach examination both show that the Rose-breasted Grosbeak makes the Colorado potato 
beetle the principal part of its food whenever it can be obtained. A case which came under my own observation will show how thoroughly they do their work. A small field of about a fourth of an acre was visited by a pair of Grosbeaks as soon as the potatoes were fairly above the ground. At first the beetles increased faster than the birds could destroy them, but after the young of the birds had hatched the beetles began to diminish, and by the time the young were able to fly the field was clear - not a beetle was to be found." *

This illustrates also the tendency of birds to prey upon some insect which, in becoming unduly abundant, offers them an unusual supply of food. Birds, for example, have been known to gather in great numbers to repel, as it were, an invasion of grasshoppers. Quoting again from Professor Beal's address: "Groundfeeding birds eat these insects at all times when they can be obtained; but in the month of August, which is the month when they attain their maximum abundance and frequently become a pest, nearly all birds, no matter what their usual food habits may be, come to the ground and eat grasshoppers. Such birds as the Baltimore Oriole, and the Cuckoo, which normally find their food upon the trees, change their habits in August and leave the trees to forage upon the ground. A few years ago, when the western part of the country was devastated by the Rocky Mountain locust, it was found that nearly every species of bird, even the larger Hawks, and Ducks and Geese, fed upon them to a considerable extent."

One of the notable achievements of the economic ornithologist has been to emphasize the value of seed-eating birds, the Sparrows, Doves, Blackbirds and others. It is a common error to believe that birds are of service to man only as insect-eaters, and that the non-insectivorous species, if not harmful, are, at least, of no particular use. But the fact is that these same insignificant looking Sparrows are the farmers' best allies in his never-ending warfare against weeds.

During the winter weed seeds form practically the entire fare of a number of species of Sparrows; the seeds of amaranth, crab grass, ragweed, and pigeon grass being the kinds devoured most frequently.

Dr. S. D. Judd, of the U. S. Department of Agriculture, who has made a special study of the food habits of seed-eating birds, states that I,OOO pigweed seeds were found in the stomach of a Snowbunting killed at Shrewsbury, Mass., in February, and that 700 seeds of pigeon grass were taken from a single Tree Sparrow; and the investigations of Professor Beal in the State of Iowa show that this species during the period of its presence, from October until April, destroyed eacin year about 875 tons of weed seeds.

* Proc. Twenty-fourth Annual Meeting New Jersey State Horticultural Society. 
Further practical evidence of the seed-eating ability of birds is furnished by Dr. Judd, who writes: "On a farm in Maryland, just outside the District of Columbia, Tree Sparrows, Fox Sparrows, White Throats, Song Sparrows and Juncos, fairly swarmed during December in the briers of the ditches between the cornfields. They came into the open fields to feed upon weed seed, and worked hardest where the smartweed formed a tangle on low ground. Later in the season the place was carefully examined. In one cornfield near a ditch the smartweed formed a thicket over 3 feet high, and the ground beneath was literally black with seeds. Examination showed that these seeds had been cracked open and the seed removed. In a rectangular space of I 8 square inches were found I, I 30 hayseeds, and only two whole seeds. Even as late as May I3, the birds were still feeding on the seeds of these and other weeds in the fields; in fact, out of a collection of I6 Sparrows 12, mainly Song, Chipping and Field Sparrows, had been eating old weed seed. A search was made for seeds of various weeds, but so thoroughly had the work been done that only half a dozen seeds could be found. The birds had taken practically all the seed that was not covered; in fact, the Song Sparrow and several others scratch up much buried seed." *

To the recent researches of the economic ornithologist we must also turn for exact information concerning the food of Hawks and Owls. No birds have been more maligned and misunderstood than these birds of prey. The misdeeds of two or three species have brought all the members of their family into disrepute. Because one Hawk has been seen to catch a chicken all Hawks are "Chicken Hawks," and, consequently, to be killed whenever opportunity offers. Not only is no protection afforded these birds by law, but in some States a bounty has been given for their destruction. Indeed, a law of this nature was passed by the Massachusetts Legislature, and the history of the so-called "Scalp Act" in Pennsylvania furnishes a convincing illustration of the direct pecuniary loss which may follow ignorance of the economical value of birds. Quoting from the report for 1886 by Dr. C. Hart Merriam, Chief of the Biological Survey of the Department of Agriculture: "On the 23d of June, r885, the Legislature of Pennsylvania passed an act known as the 'scalp act,' ostensibly 'for the benefit of agriculture,' which provides a bounty of fifty cents each on hawks, owls, weasels and minks killed within the limits of the State, and a fee of twenty cents to the notary or justice taking the affidavit.

"By virtue of this act about $\$ 90,000$ has been paid in bounties during the year

\footnotetext{
* Birds as Weed Destroyers. Year Book of U. S. Dept. of Agriculture for I898, p. 226.
} 
and a half that has elapsed since the law went into effect. This represents the destruction of at least I28,57 I of the above-mentioned animals, most of which were hawks and owls.

"Granting that 5,000 chickens are killed annually in Pennsylvania by hawks and owls, and that they are worth twenty-five cents each (a liberal estimate in view of the fact that a large portion of them are killed when very young), the total loss would be $\$ I, 250$, and the poultry killed in a year and a half would be worth $\$ 1,875$. Hence it appears that during the past eighteen months the State of Pennsylvania has expended $\$ 90,000$ to save its farmers a loss of $\$ 1,875$. But this estimate by no means represents the actual loss to the farmer and the taxpayer of the State. It is within bounds to say that in the course of a year every hawk and owl destroys at least a thousand mice or their equivalent in insects, and that each mouse or its equivalent so destroyed would cause the farmer a loss of two cents per annum. Therefore, omitting all reference to the enormous increase in the numbers of these noxious animals when nature's means of holding them in check has been removed, the lowest possible estimate of the value to the farmer of each hawk, owl, and weasel would be $\$ 20$ a year, or $\$ 30$ in a year and a half.

"Hence, in addition to the $\$ 90,000$ actually expended by the State in destroying I28,57 I of its benefactors, it has incurred a loss to its agricultural interests of at least $\$ 3,857$, I 30 , or a total loss of $\$ 3,947$, I 30 in a year and a half, which is at the rate of $\$ 2,631,420$ per ann um. In other words, the State has thrown away $\$ 2, I_{5}$ for every dollar saved! And even this does not represent fairly the full loss, for the slaughter of such a vast number of predaceous birds and mammals is almost certain to be followed by a correspondingly enormous increase in the numbers of mice and insects formerly held in check by them, and it will take many years to restore the balance thus blindly destroyed through ignorance of the economic relations of our common birds and mammals."

Detailed results of the analysis of the stomach contents of our Hawks made by the ornithologists of the U. S. Department of Agriculture fully substantiate this claim of the economic value of most of these birds and are given beyond.

Owls, because of their nocturnal habits, are even better mousers than Hawks. It is their habit to disgorge, in the form of pellets, the fur and bones of their prey, and in 675 such pellets, from the Barn Owl, taken in one of the towers of the Smithsonian Institution at Washington, Dr, A. K. Fisher found the remains of I, I I9 meadow or field mice, 4 pine mice, 452 house mice, I 34 rats, and several other species of small mammals, together with a few small birds of no especial economic importance.

No farmer whose corn in field or granary, whose potatoes and other crops have 
been damaged by the destructive field mice, can fail to realize on reading these figures what a powerful ally he has in Owls.

In the face of all these benefits conferred by birds as insect, seed, and mouseeaters, we perhaps can view more charitably the depredations of the Crows and Blackbirds in our corn and grain fields. The tarring of corn proves an effective means of making it unpalatable to Crows, but no such convenient means has been discovered for protecting fields of grain from the ravages of the hordes of Blackbirds which are attracted to them by the bountiful supply of choice food they offer, and in this instance man has so far disturbed nature's balance that the scales have been turned against him, and the bird has become an enemy rather than a friend.

\section{THE BIRD AND THE CITIZEN.}

While, indirectly, the citizen of course shares in the services rendered by birds to our agricultural interests, birds have an additional claim upon his good will. Birds destroy many undesirable insects, mosquitoes, for example, some species of which have recently been found to be so inimical to the health of the human race. Birds further increase the healthfulness of the world by acting as scavengers. It would be difficult to overestimate the value of the Buzzards, Vultures, and other offal-eating birds to the countries in which they live. In most instances the economic importance of these birds is too obvious to be overlooked, and they are, therefore, protected by law, and, by what is far more powerful than law, public sentiment.

In our Southern States the Turkey Buzzard and Black Vulture, or "Carrion Crow" have become so numerous and tame as a result of the protection there given them that they walk around the streets of the towns and cities in great numbers, and with no more evidence of fear than is shown by poultry. Every one realizes that a living Buzzard is of infinitely more value than a dead one, and in many years' experience in the South I have never seen a Buzzard molested.

In New York, it is true, we have no Buzzard, but on the waters of our seacoast, harbors, lakes and larger rivers, their place is taken by Gulls of several species, which, in feeding on the forms of aquatic life which, in dying, come to the surface, perform a sanitary service of the first importance.

While a discussion of the economic relations of birds might be supposed to confine us to a consideration of the material side of their lives, he would indeed be lacking in imaginative power, in ability to appreciate the usefulness or beauty, who did not find in these pre-eminently graceful, musical, attractive creatures a source of pleasure to mankind deserving our serious attention from the physiologic, and hence, economic standpoint. 
The pursuit which takes us afield and gives us rest and exercise combined, and increases our resources by broadening our interest in nature, is not merely a pastime, but a recreation benefiting both mind and body, and better preparing us for our duties as citizens of the State. No one would think of asserting that the value of New York's game animals was to be reckoned in the terms of the bill-of-fare. A few thousand dollars would express their wealth to the butcher or restaurateur, but to the true sportsman they are an exhaustless mine of wealth. A day with dog and gun, rod or rifle may bring small return from a pecuniary point of view, but who can calculate the amount of physical good and pure enjoyment it has afforded? Game bag and creel may, indeed, be empty, while our mind is full of stimulating experiences, all increasing our eagerness to take to the field again.

So the hunter of birds with opera glass and camera finds an even deeper pleasure in his excursions into their haunts and study of their ways; a pleasure which no accounting of the value of birds to the State can ignore.

\section{What the State Does for the Bird.}

In view of the economic importance of birds to our agricultural interests it may now well be asked what is the attitude of the State toward creatures whose welfare is so closely connected with that of its citizens? Does it take proper measures to protect them? Does it urge the employment of methods designed to aid in their increase?

It is true that the State formally recognizes the value of its assets in bird-life by the passage of laws intended to give birds legal protection, but no adequate means are provided for their enforcement. Where one person is prevented from killing a bird a thousand commit murder unchecked; nor can this evil be remedied without a material increase in the force of game wardens. The latter, as their official title implies, are appointed chiefly to enforce the laws relating to game while the laws concerning the far more numerous, and economically more valuable, non-game birds are generally dead letters.

So-called sportsmen shoot these birds in pure wantonness, pot-hunters slaughter them for market, foreigners kill them for food, milliners' agents collect them to supply fashion's demands, boys find them a tempting mark for bean-shooters and air-guns; while birds' eggs are taken as the legitimate prize of nearly every child who finds a nest. To these unnatural and remediable causes for the destruction of our birds should be added the ravages of the so-called domesticated cat. There are probably not less than two million cats in the State of New York. While many of 
them are well-fed pets, the larger proportion are to a greater or less extent dependent on their own efforts, often preferably so, for food. $A$ single cat has been known to catch sixty wild birds in a season, and a well-known naturalist and authority on the birds of New England estimates that at least 1,500,000 birds are killed annually by cats in the New England States.

It is unnecessary here to dwell on the decrease in bird-life following the clearing of forests, draining of land, accompanying the growth in our population, for this, in a measure, is unavoidable, it being my object only to show that so far as the State assumes an attitude towards the birds, that attitude is one of destruction.

\section{What the state Should Do for the Bird.}

It being demonstrated that, in the main, birds are of great value to the State, it follows that the State should spare no effort to afford its citizens of the air the protection they deserve. How, then, may we most effectively prevent the great destruction of birclife which occurs in this State? The most rational methods would appear to be: (1) Enforcement of the law; (2) licensing of cats and destruction of all non-licensed cats; (3) teaching children to realize the economic and asthetic value of birds; (4) leaving hedge rows, undergrowth, and clumps of trees as resorts for birds. The laws of the State of New York relating to birds are so well drawn that their enforcement would give our non-game birds complete legal protection from their enemy man. But, as has been said, the present force of game wardens is far too small to afford our birds the protection which is their due. What is needed, however, is not an addition to the number of game wardens, but a new officer who shall be known as a bird warden, and whose especial duty shall be to enforce the laws designed to protect non-game birds. Such officer should not only prevent the illegal killing and trapping of birds, but should examine the stock of milliners and others who offer plumage for sale.

The growing interest in the study of nature and the establishment of nature study courses in our schools, in connection with the admirable campaign to teach the people the value of birds, inaugurated by the Audubon societies and the American Ornithologists' Union, has already created a sentiment in favor of bird protection without which the best of laws are practically ineffective.

Teachers have been quick to realize that the inherent, universal interest in birdlife can be made of great educational and moral value in the training of children. No force at the State's command could effectually prevent boys from robbing nests and killing birds. Nor should the boy be prevented by force from giving this wholly 
natural exhibition of traits inherited from savage ancestors. The remedy here is to be applied, not by the State's bird wardens or police, but by its teachers. A normal, healthy boy should want to hunt birds and their nests, but a very little of the right kind of instruction at this stage of his life will often so broaden his interests that he soon finds living birds more attractive than dead ones.

As for the destruction of birds by cats, there can be no doubt that it would be largely decreased by the passage of a law requiring the annual licensing of cats, and authorizing the proper authorities to kill all non-licensed cats. Such a law should be supported not only by the friends of birds, but by the friends of cats as well. By the former because the restriction of the cat population to the well-fed tabby of the fireside would not only greatly reduce the cat population, but would do away with its worst element, the cats who hunt for a living. It should be supported by the latter because its enforcement would put an end to the existence of the many starving felines of our cities whose happiest fate is sudden death.

If birds are of value, as we believe them to be, we should not only prevent their decrease, but we should take such measures as seem calculated to assist their increase. We have seen that in destroying our forests we deprive many insectivorous birds of their homes, while in clearing hedge rows we often rob seed-eating birds of the protection the undergrowth affords them. With comparatively little trouble we can add greatly to the attractions of our farms and gardens from the birds' point of view. Clumps of trees left in the fields and rows of trees along the hedge rows will prove paying investments, and wherever it does not seriously interfere with the tilling of the land the undergrowth should be spared. During the winter food in small quantities may be used to attract birds, and in the summer water for bathing or drinking is always welcomed by them. IVren and Bluebird and Martin houses should be erected in suitable positions with the hope of securing bird tenants, who will pay a most profitable rental.

\section{The Facts in the Case.}

Thus far the results of the work of economic ornithologists have been alluded to only in a general way. It is now proposed to take up systematically the economically more important of our birds and present the known facts regarding their food-habits. In the first place, however, due mention should be made of the sources whence this information is derived and some description should be given of the manner in which it is obtained. 


\section{How A Bird's Value to Man Is Ascertained.}

To learn with scientific exactness the nature of a bird's food and then to determine whether it is an injurious or beneficial species requires especial training on the part of the investigator. He must not only be an ornithologist but he must also have a knowledge of botany and entomology. Three methods are employed by the economic ornithologist in studying a bird's food: (I) The bird may be caged in order that its dislikes, likes, and preferences, as well as the quantity of food it will consume in a given time may be ascertained; (2) the bird may be studied in nature, and (3) the contents of a bird's stomach may be examined. The lastnamed method yields by far the most definite and satisfactory results and is the one most frequently employed. While the individual student may, unassisted, make the best use of his opportunities to learn the character of a bird's food, the food habits of a species can be properly determined only through the analysis of a large number of stomachs taken at places throughout its range and representing all the seasons. Our most important investigations into the food habits of birds have, therefore, been made by specialists in the employ of the State who could secure the co-operation of others. Economic ornithologists representing the States of Illinois, New Hampshire, Massachusetts, Pennsylvania, Wisconsin, and Nebraska have contributed largely to our knowledge of the food habits of birds, but for the greater part of our exact knowledge of the economic value of our birds we are indebted to the Biological Survey of the U. S. Department of Agriculture at Washington. It is from the sources just mentioned then, and especially from the publications of the Biological Survey, that the following facts, based in the main on stomach examinations, are taken:

\section{Statistics of Food Habits.}

\section{WATER BIRDS.}

As yet practically no systematic study has been made of the food of water birds. It is known, however, that Gulls are of great service as scavengers feeding on aquatic animals which, in dying, come to the surface. The truth of this statement was very forcibly impressed on my mind, when, some years ago, I visited the lower harbor of New York Bay to see the Gulls which were attracted there by the garbage which each day at high tide was deposited on the water by the scows of the Streetcleaning Department of New York City. The number of Gulls present on this occasion was beyond calculation, but certainly exceeded three hundred thousand. Before the scows began to discharge their cargo most of the birds were resting on 
the water, but at the sound of the whistle giving the signal to dump, they arose in clouds and clustered thickly over the wake of each of the eleven scows to feed on the vegetable and animal matter thrown overboard. It was a most impressive object lesson in the economic value of these birds, which, until recently, have been destroyed in enormous numbers for millinery purposes.

In our interior States, Franklin's Gull, the Ring-billed Gull, and Black Tern feed largely on grasshoppers at certain seasons, and it is their habit to follow the plough in search of the grubs it exposes. A common sight in parts of the west, therefore, is a flock of Gulls and Terns hovering thick about the ploughman.

"The Snipe, Sandpipers, Plovers, Phalarapes, Curlews, etc.," Prof. Lawrence Bruner remarks, " are great destroyers of insects. Moving, as many of them do, in great flocks and spreading out over the meadows, pastures and hillsides, as well as among cultivated fields, they do a large amount of careful police service in arresting culprits among the insects. They even pry them out of burrows and crevices in the earth where these creatures lurk during the daytime, only to come forth after nightfall to destroy vegetation. The large flocks of Eskimo Curlew that formerly passed through Eastern Nebraska did magnificent work during years when the Rocky Mountain locust was with us, as did also the equally large flocks of Golden Plover. The Bartramian Sandpiper [Field or Upland Plover] even now is a great factor each summer in checking the increasing locusts on our prairies."

\section{LAND BIRDS. \\ GROUSE AND QUAIL. Family Gallinæ.}

Ruffed Grouse : Partridge (Bonasa nmbellus).- "Of six specimens examined two had eaten 24 caterpillars; one, the grub of a beetle, one, 2 grasshoppers, one 7 harvest-men; one, fruit ; one, foliage ; one, seeds; one, partridge berries; and three, buds.

"A young chicken [Partridge], probably not over a week old, had in its stomach I 3 caterpillars, the grub of a beetle and 7 harvest-men." +

While Partridges often feed on the buds of trees it does not appear that the habit is an injurious one, a certain amount of pruning being not undesirable.

Quail: Bob-White (Colinus virginianns).- "The Eastern Quail or Bob-White," writes Dr. Judd, $\neq$ does much good by destroying weed seeds in fields where grain has been cut and a rank growth of weeds has taken its place. Seeds of rib grass,

\footnotetext{
* Birds in their Relation to Agriculture. Proc. Nebraska Ornithologists' Union, I9or, p. 2 I.

† King, Economic Relations of Wisconsin Birds, Geology of Wisconsin, I, 59I.

$\ddagger$ Birds as Weed Destroyers. Year Book, Dept. of Agriculture. I898, p. 23 I.
} 
tickfoil, and berries of nightshade (Solanum sp.) are sometimes eaten, and pigecn grass and smartweed are frequently consumed in large quantities. The amount of grain found in the few stomachs thus far examined is surprisingly small, while the proportion of weed seed is astonishingly large, in some cases crops and gizzards being literally gorged with hundreds of seeds of ragweed."

Quail also eat potato-beetles and grasshoppers, and in Texas their food in the fall is saicl to consist " chiefly of various seeds and Mexican boll weevils, which are so disastrous to the 'Texas cotton fields." *

\section{DOVES. Family Columbidæ.}

Mourning Dove: Carolina Dove (Zcnaidura macroura).--"The Mourning Dove is abundant throughout much of the United States, and is especially common in stubble fields and waste places, grown up to weeds. It is pre-eminently a seed-eater, and although at times turning its attention to grain, it nevertheless consumes an enormous amount of weed seed. The crop of one Dove secured in a rye field in Varner, Tenn., contained 7,500 seeds of Oxalis stricta [Yellow Wood-sorrel]." (Judd.)

"In the stomach of one kind I counted 4, OI6 seeds of the pigeon grass and I 2 small snails; the latter were probably taken as gravel." (King.)

\section{HAWKS, FALCONS, ETC. Family Falconidæ.}

It was because of the widespread misunderstanding of the food habits of our Hawks and Owls, and because of their unusual economic value, that one of the first acts of the Division of Economic Ornithology, now the Biologic Survey, of the United States Department of Agriculture was to undertake a careful and elaborate study of the food of Hawks and Owls in order that their status might rest on the sound basis of observed facts.

This work was intrusted to Dr. A. K. Fisher, Assistant Ornithologist of the Survey, a naturalist of wide experience, who has won for himself a well-deserved reputation as a most careful and conscientious investigator.

After several years passed in accumulating material and in examining the contents of the stomachs of nearly 2,700 Hawks and Owls, Dr. Fisher concluded a volume of 200 pages in which are fully set forth the results of his studies. This volume forms Bulletin No. 3 of the Division of Ornithology and Mammalogy, and it is considered to be one of the most valuable contributions to economic zoology

* Schutze. The Summer Birds of Central Texas, p. 2. 
ever made. From it the following statistics in regard to the food of our Hawks and Owls are quoted:

Red-Shouldered Hawk: Chicken Hawk (Butco lineatus). - This and the following species are the commonest Hawks in the State and the ones to which the names Chicken Hawk and Hen Hawk are generally applied. The loud screaming kè kèe-yer of the Red-Shoulder as he sails far above the earth is a familiar sound and usually, though wrongly, associated by the farmer with depredations in the poultry yard.

Summary of Contents of 220 Stomachs of the Red-Shouldered Hawk. (From Fisher.)

3 stomachs contained poultry.

I 2 stomachs contained other birds.

IO2 stomachs contained mice.

40 stomachs contained other mammals.

20 stomachs contained reptiles.

39 stomach contained batrachians.

92 stomachs contained insects.

I 6 stomachs contained spiders.

7 stomachs contained crawfish.

I stomach contained earth worms.

2 stomachs contained offal.

3 stomachs contained fish.

I 4 stomachs were empty.

Red-Tailed Hawk : Chicken Hawk (Buteo borealis).-This species, of which a figure is given, is decidedly larger than the preceding. Its note is a long squealing whistle.

Summary of the Contents of 562 Stomachs of the Red-Tailed Hawk. (From Fisher.)

54 stomachs contained poultry or game birds.

5 I stomachs contained other birds.

278 stomachs contained mice.

I 3 I stomachs contained other mammals.

47 stomachs contained insects.

8 stomachs contained crawfish.

I stomach contained centipede.

I3 stomachs contained offal.

37 stomachs contained batrachians or reptiles.

89 stomachs were empty. 


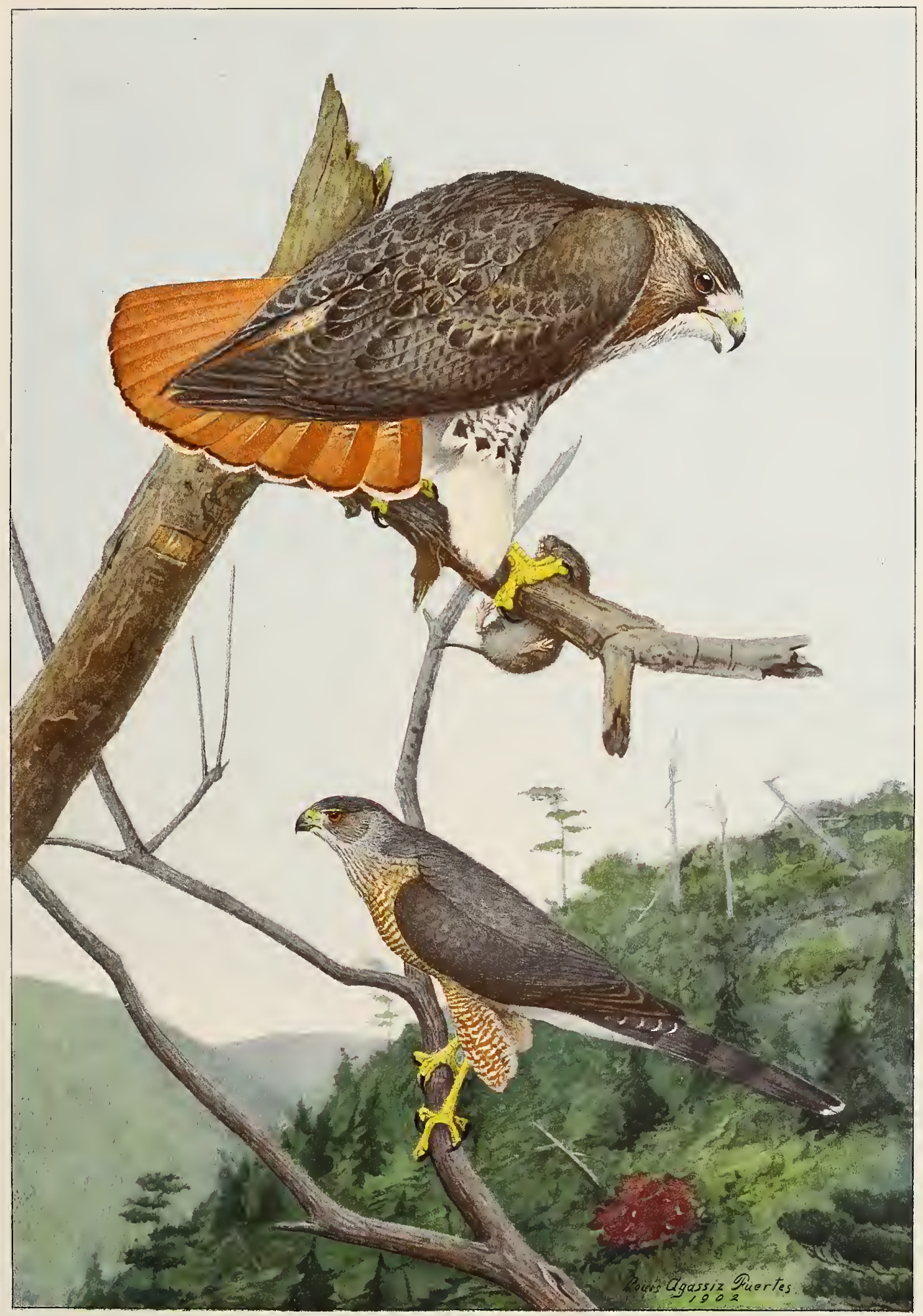

UPPER FIGURE, RED-TAILED HAWK

LOWER FIGURE, COOPER'S HAWK

ABOUT $2 / 5$ NATURAL SIZE. 

Broad-winged Hawk (Buteo platypterus). - The name "Chicken Hawk" is also applied to our Broad-winged Hawk, a somewhat smaller species than the two preceding, but closely related to them; but examination of $6_{5}$ stomachs of this bird failed to show that one bird of the number had eaten poultry. The Broad-wing's note is a high, thin, long-drawn, piercing whistle.

Summary of the Contcuts of 65 Stomachs of the Broad-winged Hawe. (From Fisher.)

2 stomachs contained small birds.

I 5 stomachs contained mice.

I 3 stomachs contained other mammals.

I I stomachs contained reptiles.

I 3 stomachs contained batrachians.

30 stomachs contained insects.

2 stomachs contained earth worms.

4 stomachs contained crawfish.

7 stomachs were empty.

Sparrow Hawk (Falco sparicrius).- When we study the food of our so-called Sparrow Hawk, we find it is a truly insectivorous bird as will be seen from the appended table:

Summary of the Contents of 320 Stomachs of the Sparrow Hawk. (From Fisher.)

I stomach contained a game bird.

53 stomachs contained other birds.

89 stomachs contained mice.

I 2 stomachs contained other mammals.

I 2 stomachs contained reptiles or batrachians.

215 stomachs contained insects.

29 stomachs contained spiders.

29 stomachs were empty.

Marsh Hawk (Circus hudsonius).-A Hawk frequently observed, because of its habits of hunting in the open, is the Marsh Hawk; he may be known by the white patch at the base of his tail above, which shows conspicuously as he flies. This species is a mouser, as appears from the following summary of the contents of I 24 stomachs : 
Summary of the Contents of 124 Stomachs of the Marsh Hawk. (From Fisher.)

7 stomachs contained poultry or game birds.

34 stomachs contained other birds.

57 stomachs contained mice.

22 stomachs contained other mammals.

7 stomachs contained reptiles.

I4 stomachs contained insects.

I stomach contained indeterminate matter.

8 stomachs were empty.

Cooper's Hawk (Accipiter cooperi).- This and the following species are the real culprits among the Hawks; for their sins all the members of the family have been made to suffer. Compared with the mouse-eating species of the genus (Buteo) they are long, slim birds (see plate), which, as a rule, never scream nor soar, but lurk quietly in ambush as becomes true hunters. Comparison of the appended tables with those giving the food of the so-called Chicken Hawks will readily show how this name has in truth been misapplied.

The question is, how are we to distinguish these bird-killing Hawks from those which should be preserved. It is a difficult matter. Probably the only safe way to give justice to whom justice is due is to kill only the Hawks we actually see taking our chickens, and not murder indiscriminately every member of the Hawk family.

Summary of the Contents of 133 Stomachs of Cooper's Hawk. (From Fisher.)

34 stomachs contained poultry or game birds.

52 stomachs contained other birds.

I I stomachs contained mammals.

I stomach contained a frog.

3 stomachs contained lizards.

2 stomachs contained insects.

39 stomachs were empty.

Sharp-Shinned Hawk (Accipiter velor).-- This species closely resemble Cooper's Hawk in color and in habits. It is, however, so much smaller that it cannot prey to much extent on poultry but lives chiefly on small birds. 
Summary of the Contents of 159 Stomachs of the Shatp-Shinned Hawk. (From Fisher.) 6 stomachs contained poultry or game birds.

99 stomachs contained other birds.

6 stomaclis contained mice.

5 stomachs contained insects.

52 stomachs were empty.

\section{OWLS. Family Bubonidæ.}

Owls, because of their nocturnal habits, prey on small rodents, themselves nocturnal, to an even greater extent than Hawks and are therefore more valuable. We continue our extracts from Dr. Fisher's work previously mentioned.

Barred Owl: Hoot Owl (Sycinium ncbulosum).- A common species much oftener heard than seen, its deep-voiced whoo-whoo-whoo, too-whoo, too-whoo-at, resembling the distant "whistle for crossing" of a locomotive, being a familiar sound to dwellers near woods.

Summary of the Contents of rog Stomachs of the Bated Owl. (From Fisher.)

5 stomachs contained poultry or game.

13 stomachs contained other birds.

46 stomachs contained mice.

IS stomachs contained other mammals.

4 stomachs contained frogs.

I stomach contained a lizard.

2 stomachs contained fish.

I4 stomachs contained insects.

2 stomachs contained spiders.

9 stomachs contained crawfish.

20 stomachs were empty.

Short-Eared Owl (Asio accipitrinus).- The Short-Eared Owl, a species which lives in our marshes, is a famous destroyer of meadow mice, as may be seen from the appended statement :

Summary of the Contents of the Stomachs of IOI Short-cared Ozuls. (From Fisher.)

I I stomachs contained small birds.

77 stomachs contained mice.

7 stomachs contained other mammals.

7 stomachs contained insects.

I4 stomachs were empty. 
Long-Eared Owl (Asio wilsonianus). - Even the excellent record of the Short. Eared Owl is excelled by that of the present species.

Summary of the Contents of Io7 Stomachs of the Long-Eared Owl. (From Fishcr.)

I stomach contained a game bird.

I5 stomachs contained other birds.

84 stomachs contained mice.

5 stomachs contained mammals.

I stomach contained insects.

I5 stomachs were empty.

Dr. T. H. Montgomery, Jr.'s study of the food habits of four individuals of this species, which roosted in an arbor vitx tree growing at his home near Philadelphia,* showed that the food of each individual averaged nearly two mice per day.

Screech Owl (Mcgascops asio). - It has been sinown that among our Hawks some species feed so largely upon insects as to be classed among the insectivorous birds, and so among our Owls we find that certain species subsist to a great extent upon insects. This will be evident on examination of the following summary of the food of our little Screech Owl:

Summary of the Contents of 255 Stonachs of the Screch Owl. (From Fisher.)

I stomach contained poultry.

38 stomachs contained other birds.

9I stomachs contained mice.

I I stomachs contained other mammals.

2 stomachs contained lizards.

4 stomachs contained batrachians.

I stomach contained fish.

IOO stomachs contained insects.

5 stomachs contained spiders.

9 stomachs contained crawfish.

7 stomachs contained miscellaneous matter.

2 stomachs contained scorpions.

2 stomachs contained earth worms.

43 stomachs were empty.

\footnotetext{
* The American Naturalist, I899, p. 563 .
} 


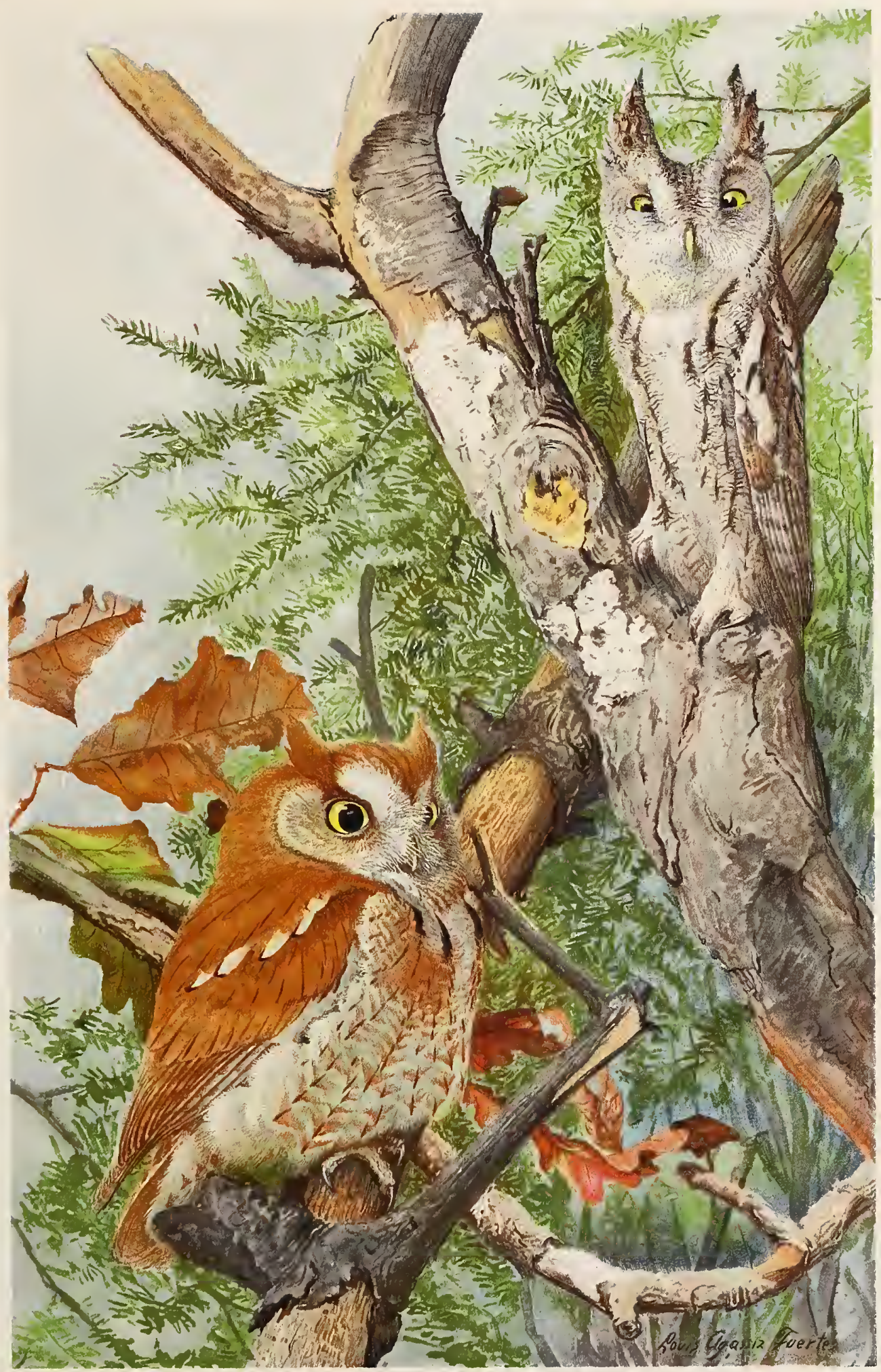



Great Horned Owl (Bubo virginianus).-- While this large Owl feeds on both poultry and game birds it also preys upon mammals, some of which may be injurious. As a rule, however, the bird is so uncommon near civilization, and so quickly disappears with the fall of the forests that its relations to man are at the best indirect.

Summary of the Contents of 127 Stomachs of the Groat Horned Owl. (From Fisher.)

3 I stomachs contained poultry or game birds.

8 stomachs contained other birds.

I 3 stomachs contained mice.

65 stomachs contained other mammals.

I stomach contained a.scorpion.

IO stomachs contained insects.

I7 stomachs were empty.

\section{CUCKOOS. Family Cuculidæ.}

Cuckoos, of which we have two species, the Yellow-billed and Black-billed, are great destroyers of caterpillars. In Farmers' Bulletin No. 54 of the United States Department of Agriculture, Professor Beal writes of them as follows :

"An examination of thirty-seven stomachs has shown that these Cuckoos are much given to eating caterpillars, and, unlike most birds, do not reject those covered with hair. In fact, Cuckoos eat so many hairy caterpillars that the hairs pierce the inner lining of the stomach and remain there, so that when the stomach is opened and turned inside out, it appears to be lined with a thin coating of fur."

Black-Billed Cuckoo (Coccyaus crythrophthalmus).- "An examination of the stomachs of sixteen Black-billed Cuckoos, taken during the summer months, showed the remains of 328 caterpillars, eleven beetles, fifteen grasshoppers, sixty-three sawflies, three stink bugs, and four spiders. In all probability more individuals than these were represented, but their remains were too badly broken for recognition. Most of the caterpillars were hairy, and many of them belonged to a genus that lives in colonies and feeds on the leaves of trees, including the apple tree. One stomach was filled with larvæ of a caterpillar belonging to the same genus as the tent caterpillar, and possibly to that species. Other larvæ were those of large moths, for which the bird seems to have a special fondness. The beetles were for the most part click beetles and weevils, with a few May beetles, and some others. The sawflies were all found in two stomachs, one of which contained no less than sixty in the larval stage." (Beal.) 
Yellow-Billed Cuckoo (Coccyzus americanns).--" Of the Yellow-billed Cuckoo, tiventy-one stomachs (collected from May to October, inclusive) were examined. The contents consisted of 355 caterpillars, eighteen beetles, twenty-three grasshoppers, thirty-one sawflies, fourteen bugs, six flies, and tivelve spiders. As in the case of the Black-Billed Cuckoo, most of the caterpillars belong to hairy species, and many of them were of large size. One stomach contained twelve Americar tent caterpillars; another 217 fall webworms. The beetles were distributed among several families, but all more or less harmful to agriculture. In the same stomach which contained the tent caterpillars were two Colorado potato beetles; in another were three goldsmith beetles and remains of several other large beetles; besides ordinary grasshoppers were several katydids and three crickets. The sawflies were in the laval stage, in which they resemble caterpillars so closely that they are commonly called false caterpillars by entomologists, and, perhaps, this likeness may be the reason the Cuckoos eat them so freely. The bugs consisted of stink bugs and cicadas or dogday harvest flies, with the single exception of one wheel bug. which was the only useful insect eaten, unless the spiders be counted as such." (Beal.)

\section{KINGFISHER. Family Alcedinidæ.}

Kingfisher (Corylo alcyou).-- Our one species of this family is rated destructive by fishculturists and is denied legal protection. We must remember, however, that value of birds to man which cannot be expressed in dollars and cents. The Kingfisher is far too interesting and characteristic a feature of our ponds, lakes and waterways to be exterminated. Admitting that certain individuals of the species are injurious, it does not follow that the whole race should be condemned.

\section{WOODPECKERS. Family Picidæ.}

"Farmers are prone to look upon Woodpeckers with suspicion. When the birds are seen scrambling over fruit trees and pecking at the bark, and fresh holes are found in the tree, it is concluded that they are doing harm. Careful observers, however, have noticed that, excepting a single species, these birds rarely leave any important mark on a healthy tree, but that when a tree is affected by wood-boring larvæ, and insects are accurately located, dislodged, and devoured. In case the holes from which the borers are taken are afterwards occupied and enlarged by colonies of ants, these ants in turn are drawn out and eaten." (Beal.)

Downy Woodpecker (Dryobates pubesccus). - This our smallest and most 


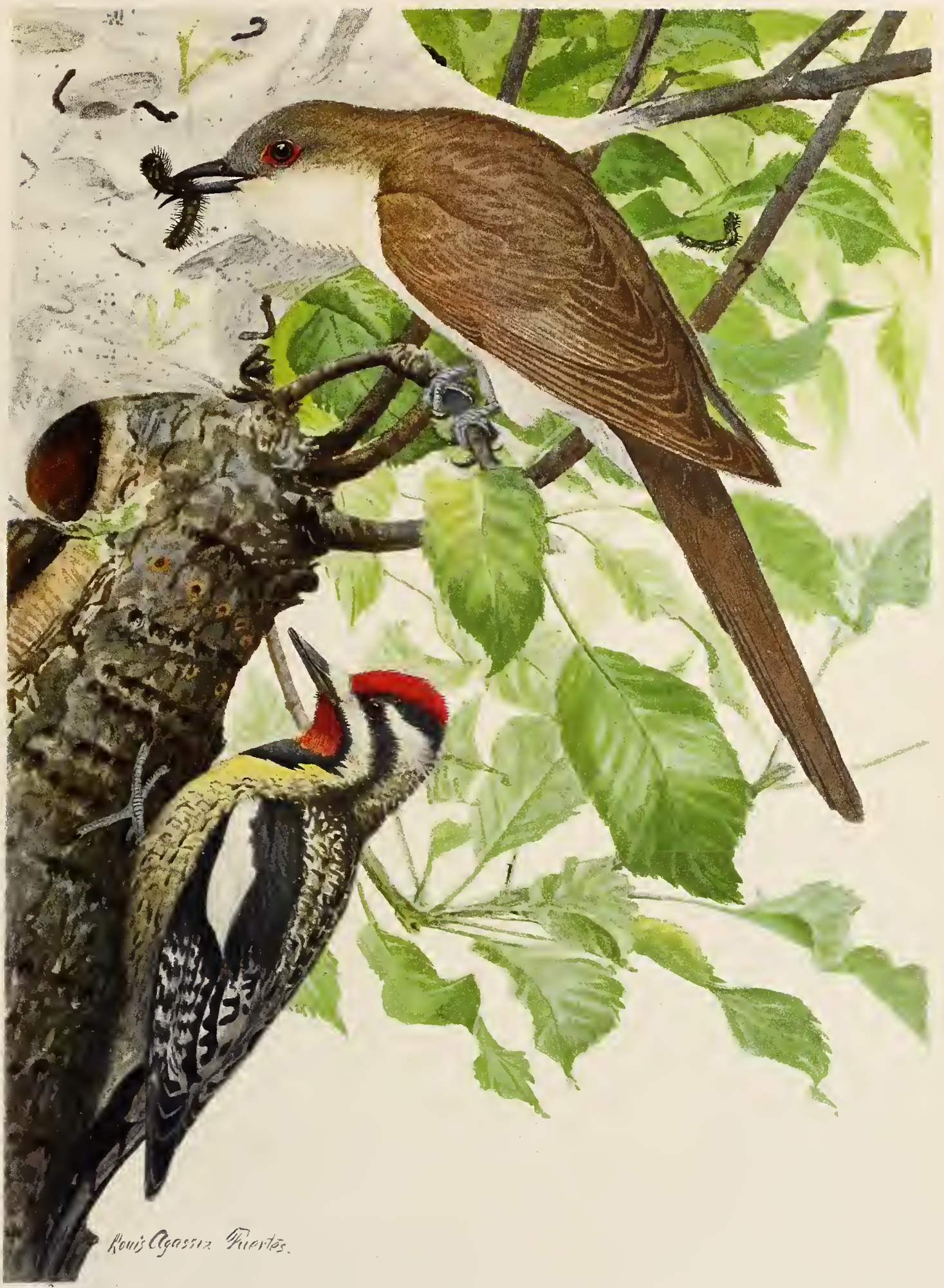

UPPER FIGURE, BLACK-BILLED CUCKOO

LOWER FIGURE, YELLOW-BELLIED SAPSUCKER

ABOUT $3 / 5$ NATURAL SIZE. 

common Woodpecker (see plate), is also the most beneficial. Professor Beal* states that 75 per cent of its food consists of insects, including ants, beetles, bugs, flies, caterpillars, and grasshoppers.

King found in the stomachs of this species wood-boring grubs, larva, caterpillars, ants, beetles, and other insects. The species also feeds to a small extent on wild fruits.

Hairy Woodpecker (Dryobates villosus). - This, species resembles the preceding in color, but is longer. According to Beal 68 per cent of its food is animal matter 2 I per cent of the whole food being caterpillars. The same writer states that F. M. Webster saw this species peck a hole in the cocoon of a cecropia moth and devour its contents; only 2 out of 20 cocoons examined being uninjured.

King found I I larvæ of wood-boring beetles and 12 geometers in the stomach of one Hairy Woodpecker; another contained I3 larvæ of long-horned beetles and 4 cockroach oötheca.

Flicker : Clape : High-hole: Golden-Winged Woodpecker (Colaptes auratus).In some States this Woodpecker is ranked as a game bird and its killing is permitted at certain seasons. Study of the bird's food, however, shows that it should at all times be protected. While feeding on wild fruits, the bird's chief economic value is derived from its destruction of ants which, Professor Beal states, constitute 43 per cent of its whole food. In each of two stomachs of the Flicker examined by this investigator were found over 3,000 ants; Bruner states that the stomach of a Flicker killed near Lincoln, Nebraska, contained nearly I,,oo Chinch bugs.

Pileated Woodpecker: Logcock (Ceophlous pileatus). - This fine large species is now confined to the most heavily forested portions of the State. The trunk of a white pine, fallen but as yet externally sound, which I examined in Vermont, showed twelve cavities made by this bird in its search for wood-boring larvæ. The largest was twelve inches long, four inches wide, and eight inches deep. The heart of the tree proved to be riddled by the passages of the borers which the Woodpecker, when alighting on the tree, had doubtless heard at work.

While most of the wood-borers eaten by this species are obtained from dead trees, the borers begin their work in living trees and any agent which tends to hold them in check is therefore of value to our forests.

Red-Headed Woodpecker (Melanerpes erythrocephalus)._- "The Red-Headed Woodpecker (Melanerpes erythrocephalus) is well known east of the Rocky Mountains, but is rather rare in New England. Unlike some other species, it pre.

\footnotetext{
* Preliminary Report on the Food of Woodpeckers. Bull. No. 7, Biological Survey, U. S. Dept. of Agriculture.
} 
fers fence posts and telegraph poles to trees as a foraging ground. Its food, therefore, naturally differs from that of the preceding species, and consists largely of adult beetles and wasps which it frequently captures on the wing, after the fashion of flycatchers. Grasshoppers also form an important part of the food. The Redhead has a peculiar habit of selecting very large beetles, as shown by the presence of fragments of several of the largest species in the stomachs. Among the beetles were quite a number of predaceous ground beetles, and unfortunately some tiger beetles, which are useful insects. The Redhead has been accused of robbing the nests of other birds; also of attacking young birds and poultry and pecking out their brains, but as the stomachs showed little evidence to substantiate this charge it is probable that the habit is rather exceptional."

Yellow-Bellied Sapsucker (Sphyrapicus varius).-It is this species which is responsible for the numerous rows of holes so commonly seen in the trunks of apple and other trees. They are made to supply the bird with sap and when numerous may result in the death of the tree through girdling. The Sapsucker also feeds upon the insects which are attracted to the sap flowing from the punctures it has made, but that the bird is primarily a sap-eating rather than insect-eating species is apparently shown by its brushy, instead of spiny-tipped, tongue.

The Sapsucker, then, may become an injurious species when it pays too close attention to one tree, riddling a section of its bark so thickly that circulation is destroyed and death follows.

\section{NIGHTHAWK AND WHIP-POOR-WILL. Family Caprimulgidæ.}

Both the Nighthawk and Whip-Poor-Will feed exclusively on insects, and feeding at dusk and by night, when other birds are sleeping, they do unusually good service by devouring species which might otherwise escape.

Nighthawk (Chordeiles virginianus).- - The food of the Nighthawk consists of moths. beetles, including June bugs, ants, grasshoppers, flies, mosquitoes, and crickets. Mrs. Bailey mentions one bird of this species, the stomach of which contained 573 large winged ants, parts of 72 small winged ants, and 16 grasshoppers.

In the south, where the Nighthawk is known as Bull-bat, it is often shot for so-called sport in large numbers, though the facts show that no bird is more deserving of protection.

Whip-poor-will (Antrostornus vociferus). - The Whip-poor-will feeds nearer the ground than the Nighthawk and is more often seen than heard. It eats ants, grasshoppers, potato beetles, June bugs, moths, and other winged insects. 


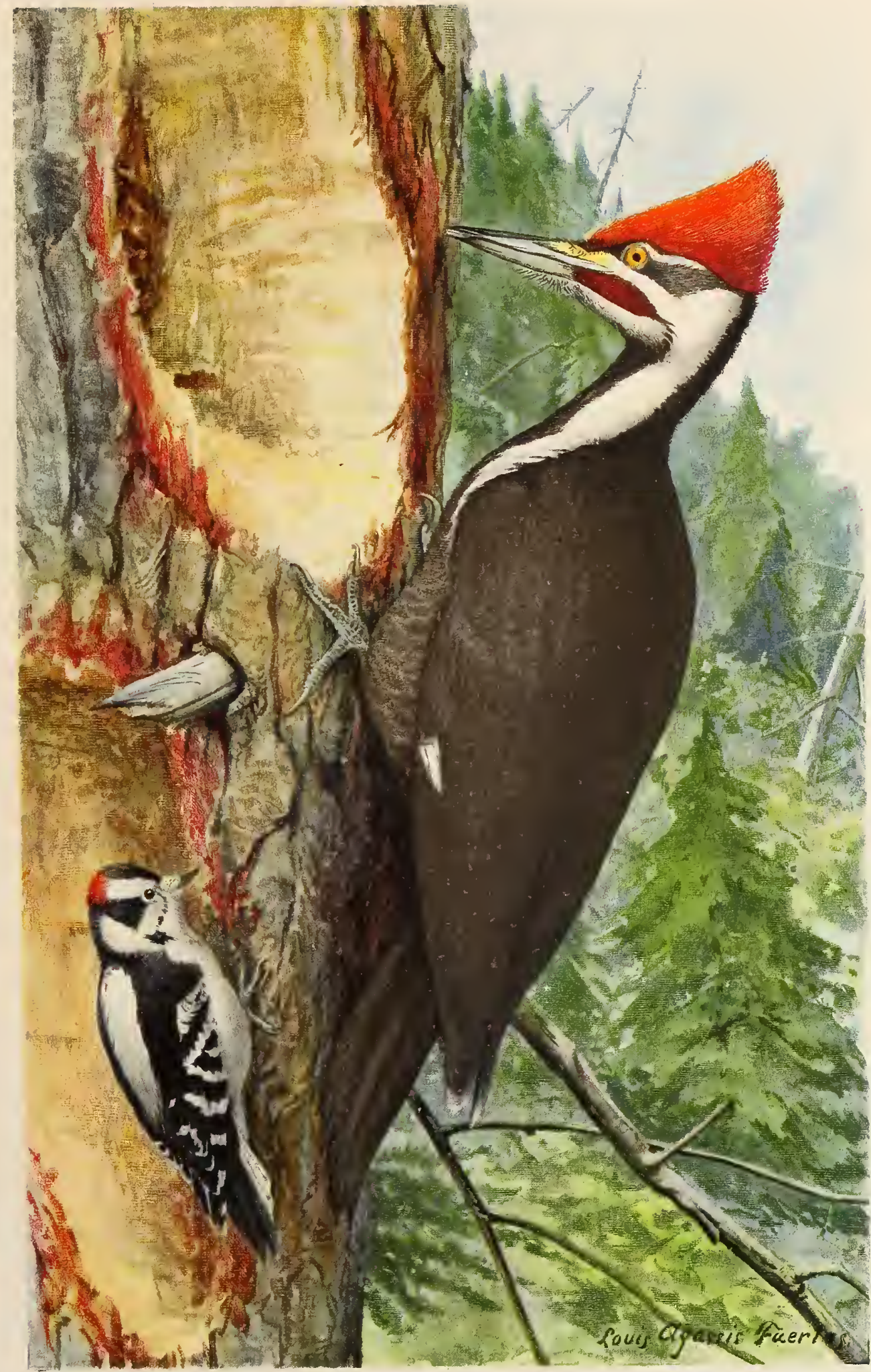

UPPER FIGURE, PILEATED WOODPECKER

LOWER FIGURE, DOWNY WOODPECKER

ABOUT $1 / 2$ NATURAL SIZE. 



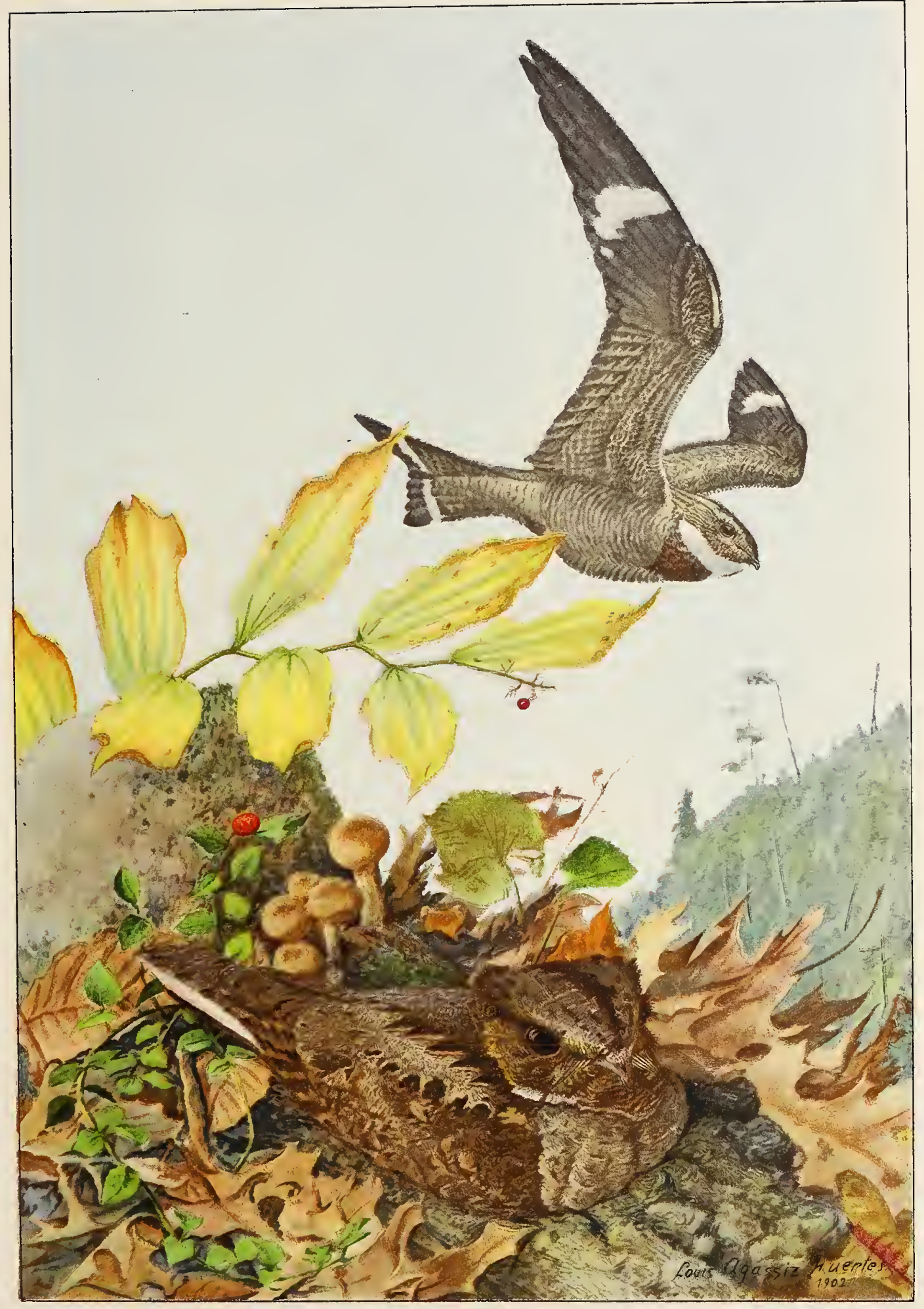

UPPER FIGURE, NIGHTHAWK

$1 / 3$ NATURAL SIZE.

LOWER FIGURE, WHIP-POOR-WILL

$1 / 2$ NATURAL SIZE. 



\section{SWIFTS. Family Micropodidæ.}

Chimney Swift (Chatura pelagica).-No detailed study of the food of the Chimney Swift appears to have been made. The species, however, so far as known, is exclusively insectivorous and in view of its abundance is doubtless of much economic importance.

\section{HUMMINGBIRDS. Family Trochilidæ.}

Ruby-Throated Hummingbird (Trochilus colubris).- The juices of plants, spiders, plant-lice, and other sinall insects constitute the food of the Hummingbird, which also may be of service in pollenizing the flowers it visits.

\section{FLYCATCHERS. Family Tyrannidæ.}

As their name indicates, the birds of this family are insectivorous. The food habits of only four species appear to have been more than superficially studied.

Kingbird (Tyranus tyrannus).- "In its food habits this species is largely insectivorous. It is a true flycatcher by nature, and takes a large part of its food on the wing. It does not, however, confine itself to this method of hunting, but picks up some insects from trees and weeds, and even descends to the ground in search of myriapods or thousand legs. The chicf complaint against the Kingbird is that it preys largely upon honeybees; and this charge has been made both by professional bee keepers and others. Many observers have seen the bird at work near hives, and there is no reason to doubt the honesty of their testimony. One bee raiser in Iowa, suspecting the Kingbirds of feeding upon his bees, shot a number near his hives, but when the birds' stomachs were cxamined by an expert entomologist not a trace of loneybecs could be found.

"The Biological Survey has made an cxamination of 281 stomachs collected in various parts of the country, but found only 14 containing remains of honeybees. In these 14 stomachs there were in all 50 honeybees, of which 40 were drones, 4 were certainly workers, and the remaining 6 were too badly broken to be identified as to sex.

"The insects that constitute the great buik of the food of this bird are noxious species, largely beetles - May bectles, click beetles (the larve of which are known as wire worms), weevils, which prey upon fruit and grain, and a host of others. Wasps, wild bees, and ants are conspicuous elements of the food, far outnumbering the hive bees. During summer many grasshoppers and crickets, as well as leaf hoppers and other bugs, are also eaten. Among the flies were a number of robber flics 
- insects which prey largely upon other insects, especially honeybees, and which have been known to commit in this way extensive depredations. It is thus evident that the Kingbird by destroying these flies actually does good work for the apiarist. Nineteen robber flies were found in the stomachs examined; these may be considered more than an equivalent for the four worker honeybees already mentioned. A few caterpillars are eaten, mostly belonging to the group commonly known as cutworms, all the species of which are harmful. About io per cent of the food consists of small native fruits, comprising some twenty common species of the roadsides and thicket, such as dogwood berries, elder berries, and wild grapes. The bird has not been reported as eating cultivated fruit to an injurious extent, and it is very doubtful if this is ever the case, for cherries and blackberries are the only ones that might have come from cultivated places, and they were found in but few stomachs.

"Three points seem to be clearly established in regard to the food of the Kingbird - (I) that about 90 per cent consists of insects, mostly injurious species ; (2) that the alleged habit of preying upon honeybees is much less prevalent than has been supposed, and probably does not result in any great damage; and (3) that the vegetable food consists almost entirely of wild fruits which have no economic value. These facts, taken in connection with its well-known enmity for Hawks and Crows, entitle the Kingbird to a place among the most desirable birds of the orchard or garden." (Beal.)

Phoebe (Sayornis phobe).— "The Phoebe subsists almost exclusively upon insects, most of which are caught upon the wing. An examination of 80 stomachs showed that over 93 per cent of the year's food consists of insects and spiders, while wild fruit constitutes the remainder. The insects belong chiefly to various species and include many click beetles, May beetles, and weevils. Grasshoppers in their season are eaten to a considerable extent, while wasps of various species, many flies of species that annoy cattle, and a few bugs and spiders are also eaten. * * *

"There is hardly a more useful species about the farm and it should receive every encouragement. To furnish nesting boxes is unnecessary, as it usually prefers a more open situation, like a shed or nook under the eaves, but it should be protected from cats and other marauders." (Beal.)

Wood Pewee (Contopus virens)._- "Of forty-one specimens examined, eighteen had eaten 66 small beetles, among them 7 metallic-green beetles and several lamellicorns ; fourteen, $4 \mathrm{I}$ dipterous insects, among them I 2 large crane-flies. * * *

"I have seen one Wood Pewee capture and feed to its young, which had recently left the nest, $4 \mathrm{I}$ insects in the course of $4 \mathrm{I}$ minutes. Several of these insects were moths." (King.) 


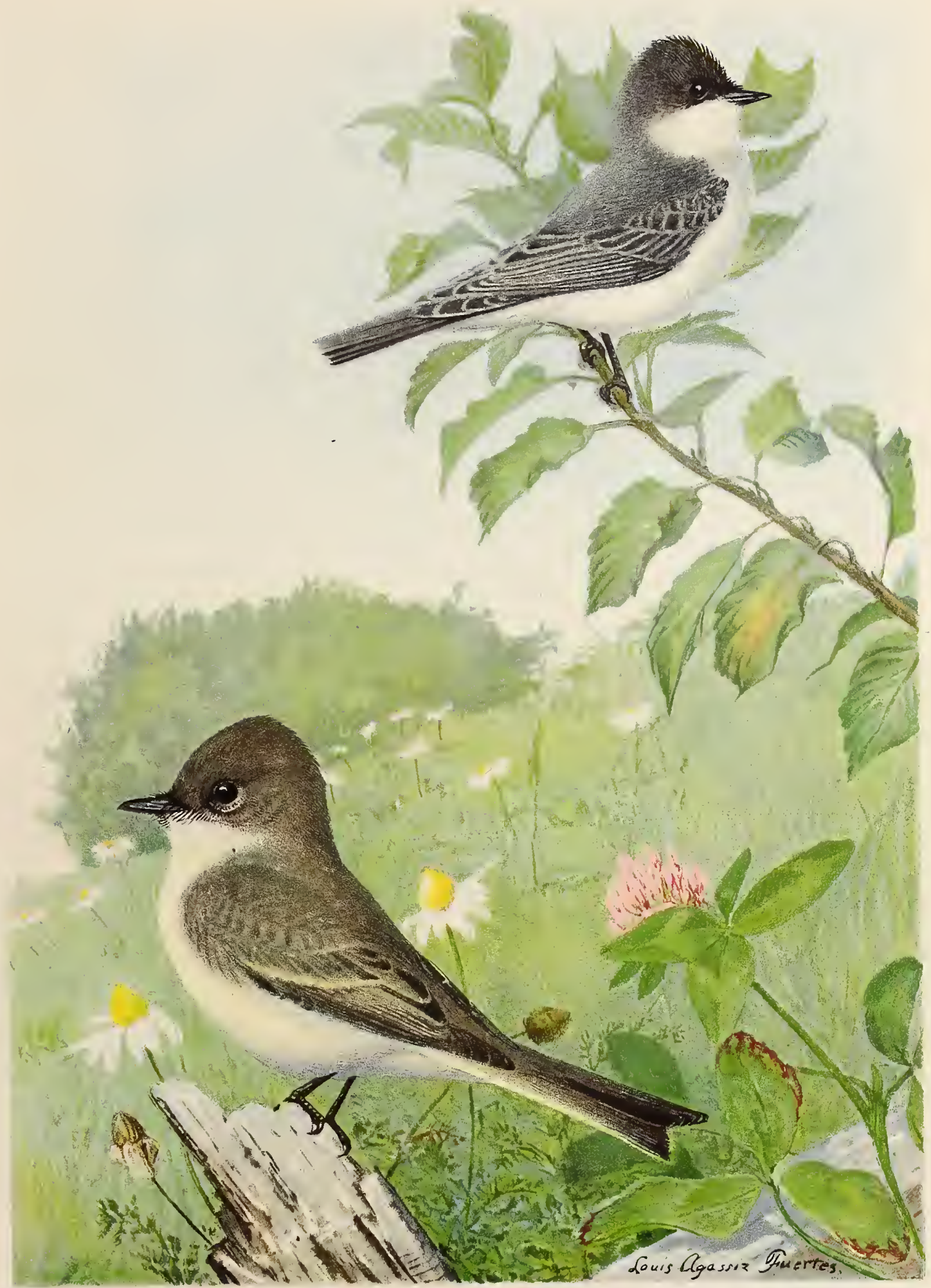

UPPER FIGURE, KINGBIRD ABOUT $1 / 2$ NATURAL SIZE.

LOWER FIGURE, PHOEBE ABOUT $2 / 3$ NATURAL SIZE. 

Least Flycatcher: Chebec (Empidonax minimus).—- "Of twenty-three specimens examined ten had eaten 30 beetles - among them 2 squash beetles (Diabrothca vittata), a lady-bird and 2 weevils; four, is dipterous insects; one, 2 small heteropterous insects, equal in size to Chinch bug; four, 39 hymenopterous insects, 2 small ichneumon flies and 37 winged-ants; two, 3 caterpillars; one, a moth; two, 4 small dragon-flies; and one, a small spider." (King.)

\section{LARKS. Fanily Alaudidæ.}

Horned Lark (Otocoris alpestris). - The Horned Larks, including this, the winter visitant form and the Prairie Horned Lark (O.a.praticola), which breeds throughout the central portion of the State, are of economic value as weed-seed eaters; while the latter also eats various species of insects. No detailed study of their food has been published.

\section{CROWS and JAYS. Family Corvidæ.}

To the members of this family are attributed numerous misdeeds, and although much attention has been given to their food habits, their injurious habits are said to be so nearly balanced by beneficial ones that it is difficult to determine which outweighs the other.

Crow (Corvus americanus).- " That he [the Crow] does pull up sprouting corn, destroy chickens, and rob the nests of small birds has been repeatedly proved. Nor are these all of his sins. He is known to eat frogs, toads, salamanders, and some small snakes, all harmless creatures that do some good by eating insects. With so many charges against him, it may be well to show why he should not be utterly condemned.

"The examination of a large number of stomachs, while confirming all the foregoing accusations, has thrown upon the subject a light somewhat different from that derived solely from field observation. It shows that the birds-nesting habit, as in the case of the Jay, is not so universal as has been supposed; and that, so far from being a habitual nest robber, the Crow only occasionally indulges in that reprehensible practice. The same is true in regard to destroying chickens, for he is able to carry off none but the very young ones, and his opportunities for capturing them are somewhat limited. Neither are many toads or frogs eaten, and as frogs are of no great practical value, their destruction is not a serious matter; but toads are very useful, and their consumption, so far as it goes, must be counted against the Crow. Turtles, crayfishes, and snails, of which he eats quite a large number, may be considered neutral, while mice may be counted to his credit. 
"In his food, however, the Crow makes amends for his sins in the rest of his dietary, although even here the first item is against him. Predaceous beetles are eaten in some numbers throughout the season, but the number is not great. May beetles, 'dor-bug,' or June bugs, and others of the same family, constitute the principal food during spring and early summer, and are fed to the young in immense quantities. Other beetles, nearly all of a noxious character, are eaten to a considerable extent. Grasshoppers are first taken in May, but not in large numbers until August, when, as might be expected, they form the leading article of diet, showing that the Crow is no exception to the general rule that most birds subsist, to a large extent, upon grasshoppers in the month of August. Many bugs, some caterpillars, mostly cutworms, and some spiders, are also eaten - all of them either harmful or neutral in their economic relations. Of the insect diet Mr. E. A. Schwarz says: 'The facts, on the whole, speak overwhelmingly in favor of the Crow.'

"Probably the most important item in the vegetable food is corn, and by pulling the newly sprouted seeds the bird renders himself extremely obnoxious. Observations and experiments with tame Crows show that hard, dry corn is never eaten if anything else is to be had, and if fed to nestlings it is soon disgorged. The reason Crows resort to newly planted fields is that the kernels of corn are softened by the moisture of the earth, and probably become more palatable in the process of germination, which changes the starch of the grain to sugar. The fact, however, remains that the Crows eat corn extensively only when it has been softened by germination or partial decay, or before it is ripe and still ' in milk.' Experience has shown that they may be prevented from pulling up young corn by tarring the seed, which not only saves the corn but forces them to turn their attention to insects. If they persist in eating green corn it is not easy to prevent the damage; but no details of extensive injury in this way have yet been presented, and it is probable that no great harm has been done.

"Crows eat fruit to some extent, but confine themselves for the most part to wild species, such as dogwood, sour gum, and seeds of the different kinds of sumac. They have also a habit of sampling almost everything which appears eatable, especially when food is scarce. For example, they eat frozen apples, found on the trees in winter, or pumpkins, turnips, and potatoes which have been overlooked or neglected; even mushrooms are sometimes taken, probably in default of something better.

"In estimating the economic status of the Crow, it must be acknowledged that he does some damage, but; on the other hand, he should receive much credit for the insects which he destroys. In the more thickly settled parts of the country the 
Crow probably does more good than harm, at least when ordinary precautions are taken to protect young poultry and newly planted corn against his depredations. If, however, corn is planted with no provision against possible marauders, if hens and turkeys are allowed to nest and to roam with their broods at a distance from farm buildings, losses must be expected."

While, from the nature of the case, birds' eggs and young birds can form but a small portion of the annual food-supply of the Crow, I believe it to be indisputable that during the nesting season they constitute a large percentage of the Crow's food. Nestrobbing is not occasional but is the characteristic habit of the Crow. Not only do they eat eggs and young birds, but they feed their offspring on them. Doubtless few Crows live through May and June without preying on smaller birds and the possibilities are that almost any one of the birds cestroyed (either in the egg or out of it) is of greater economic value than the Crow. The Crow, therefore, in addition to the direct damage it may do our crops, robs us of the services of birds far more desirable than itself. Even if the Crow, aside from its cannibal-like propensities, was wholly beneficial, it would not, it seems to me, render us as great a service as would have been performed by the birds it destroys. In short, in my opinion, the Crow is one of the worst enemies of our small insectivorous and seedeating birds, and as such it is undeserving of protection.

Blue Jay (Cyanositta cristata).-.." The Blue Jay is a common bird of the United States east of the Great Plains, and remains throughout the year in most of its range, although its numbers are somewhat reduced in winter in the Northern States. During spring and summer the Jay is forced to become an industrious hunter for insects, and is not so conspicuous a feature of the landscape as when it roams the country at will after the cares of the nesting season are over.

"Ornithologists and field observers in general declare that a considerable portion of its food in spring and early summer consists of the eggs and young of small birds, and some farmers accuse it of stealing corn to an injurious extent in the fall. While there may be some truth in these accusations, they have almost certainly been exaggerated. No doubt many Jays have been observed robbing nests of other birds, but thousands have been seen that were not so engaged.

"In an investigation of the food of the Blue Jay 292 stomachs were examined which showed that animal matter comprised $24 \%$ and vegetable matter $76 \%$ of the bird's diet. So much has been said about the nest-robbing habits of the Jay that special search was made for traces of birds or birds' eggs in the stomachs, with the result that shells of small birds' eggs were found in three and the remains of young birds in only two stomachs. Such negative evidence is not sufficient to controvert 
the great mass of testimony on this point, but it shows that the habit is not so prevalent as has been believed. Besides birds and their eggs, the Jay eats mice, fish, salamanders, caterpillars, snails, and crustaceans, which altogether constitute but little more than I per cent of its diet. The insect food is made up of beetles, grasshoppers, caterpillars, and a few species of other orders, all noxious, except.some $3 \frac{1}{2} \%$ of predaceous beetles. Thus something more than $19 \%$ of the whole food consists of harmful insects. In August the Jay, like many other birds, turns its attention to grasshoppers, which constitute nearly one-fifth of its food during that month. At this time, also, most of the other noxious insects, including caterpillars, are consumed, though the beetles are chiefly eaten in spring.

"The vegetable food is quite varied, but the item of most interest is grain. Corn was found in 70 stomachs, wheat in 8 , and oats in 2, all constituting $19 \%$ of the total food. Corn is evidently the favorite grain, but a closer inspection of the record shows that the greater part was eaten during the first five months of the year, and that very little was taken after May, even in harvest time, when it is abundant. This indicates that most of the corn is gleaned from the fields after harvest, except what is stolen from the cribs or gathered in May at planting time.

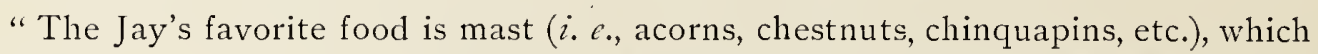
was found in I 58 of the 292 stomachs and amounted to more than $42 \%$ of the whole food. In September corn formed I 5 and mast 35\%, while in October, November and December corn dropped to an almost inappreciable quantity, and mast amounted to 64,82 and $83 \%$, respectively. And yet in these months corn is abundant and everywhere accessible. The other elements of food consist of a few seeds and wild fruits, among which grapes and blackberries predominate.

"The results of the stomach examination show, (I) that the Jay eats many noxious insects; (2) that its habit or robbing the nests of other birds is much less common than has been asserted; and (3) that it does little harm to agriculture, since all but a small amount of the corn eaten is waste grain." (Beal.)

Personally, my attitude toward the Jay is that which I hold in regard to the Crow. It is not unusual for the Jay to eat birds' eggs, and in so doing he does an injury which the good deeds to his credit are far from balancing. As with the Crow, any one of the insect or seed-eating birds killed by a Jay would doubtless have been more desirable than the Jay itself, and where a single Jay, as often happens, destroys a whole nestful of eggs it becomes a positively injurious species. I believe, therefore, that the Blue Jay is no more deserving of protection than is the Crow. Both birds, however, are far too interesting to be exterminated, but no steps should be taken which will result in their increase. Belonging to a family 
noted for the intelligence and adaptability of its members, Crows and Jays can adjust themselves to the changes incident to civilization far morc readily than many of the birds which become their victims, and, in cases of this kind, man should help to restore nature's balance by according protection to the weaker species; not to their enemies.

\section{STARLINGS. Family Sturnidae.}

Starling (Sturnus vulgaris).- The Starling was first successfully introduced into this country by Mr. Eugene Schieffelin, under whose direction so birds were released in Central Park, New York City, March 6, I890; and 40 more on April 25, I89I. There was evidently room in this new environment for these birds for they so thrived that their descendants are now numbered by thousands; flocks containing several hundred being frequently seen in the upper part of New York City and eastward along the sound.

The Starling, therefore, is now firmly established in this country, and if it continues to multiply at the rate already shown to be possible, it will in comparatively few years become one of our most abundant birds.

Whether this species will prove to be beneficial or injurious it is difficult to surmise. In its own habitat it is said to be on the whole economically valuable; but under wholly new surroundings, where its relations to other species are as yet undetermined, one cannot predict what its place in nature will be. There can be no question, however, that the present is the time to give this matter serious consideration. In a few years Starlings will be as far beyond control as English Sparrows are now.

\section{BLACKBIRDS, ORIOLES, ETC. Family Icteridae.}

In this family are included several species reputed to be the worst enemies, among birds, to the farmer. The Blackbirds, of several species, are especially condemned as grain destroyers. Raising only one brood they begin to flock early in July and before the grain is harvested have gathered in enormous bodies which unquestionably do much damage. It is, therefore, not without cause that our law refuses Blackbirds protection at all seasons. The question is, shall we go further than this? Shall we attempt to reduce the numbers of these birds? On this point Professor Beal writes : *

"In a treatise on the destructiveness of grain-eating birds it is natural that the reader should expect at least a suggestion of a remedy. Unfortunately it is much 
easier to point out the evil than to prescribe the cure. Stomach investigation shows conclusively that birds do not subsist upon grain alone, even at times when it is possible to obtain it. Moreover, the greatest amount of grain is not eaten at harvest time, but during the winter months, when other food is scarce and waste kernels can be picked up in the fields. If any kind of grain is preferred by a certain species, we should expect the bird to subsist upon that grain almost exclusively when it can be obtained, that is, at harvest time. That this is not the case is shown by the fact that many birds of the same species have been shot at the same time in a grainfield, and while some stomachs were full of grain, others were only partly filled, and still others were wholly filled with other food. So many cases of this kind have occurred that it seems practically certain that few birds willingly subsist exclusively upon any kind of grain for a considerable length of time. With many species this is in notable contrast to their marked fondness for the seeds of certain useless plants, upon which at some seasons they subsist almost entirely.

"If it be admitted that birds do not as a rule display an inordinate appetite for" grain, the question naturally arises: What is the cause of the tremendous ravages they sometimes commit? Both stomach examination and field observation point to the same answer: Too many birds of the same or closely allied species are gathered together within a limited area.

"As already pointed out, the Upper Mississippi region presents such exceptionally favorable breeding grounds for Blackbirds, especially the Redwing and Yellowhead, that they swarm there in countless numbers. Settlement and cultivation have not yet encroached materially upon their haunts, but have added a source of food, which, coming before the great natural supply, has served to render the race more vigorous and prolific.

"An attempt to exterminate these species would be not only ill-advised but hopeless. States have offered bounties for their destruction without perceptibly thinning their ranks. Is there, then, any remedy for the evil? The writer is forced to confess that he has none to suggest, except in the case of Crows and Blackbirds that pull up sprouting corn. This can be prevented by thoroughly tarring the seed, which, if properly done, neither injures its vitality nor prevents the use of machinery in planting. There is, however, some hope for the future, though perhaps a distant one. While the advance of civilization has thus far not affected these birds or their haunts, the time must surely come when it will. Increased density of population will broaden the area of cultivation, and this in time must lead to the draining of the smaller marshes and ponds, thus turning over to agriculture much land that has heretofore been worse than waste, since it has served as a 
breeding ground for the birds that have destroyed the crops. With the breeding places more restricted and an environment otherwise changed by increased population, the number of birds must surely decrease, and in time the proper equilibrium will be restored. In the meantime, it behooves the farmer to apply such remedies as the exigencies of the case suggest, and where these gregarious species are overabundant it might be well to exempt them from the general protective laws, in order that each landholder may be free to protect himself as best he can."

Crow Blackbird: Purple Grackle and Bronzed Grackle (Quiscalus quiscula ct ancus.)- "Crow Blackbirc's are fond of grain, and being of good size and abundant, evidently have the power to do great harm. Moreover, the examination of more than 2,000 of their stomachs shows that grain formed 45 per cent of the food of the year, and that corn alone constitutes 35 per cent. From this it might be expected that they would attract much attention from grain growers, and such is the case. Hundreds of communications have been received testifying to their destructiveness : yet many of these acknowledge the fact that Blackbirds eat a large quantity of insects, especially during the breeding season, and that many insects are fed to the young. This last is also borne out by stomach examination. A review of the yearly diet shows that the greater part of the corn eaten is taken during the fall and winter months. That eaten in winter and early spring (March and April), except the small quantity taken from corncribs, must be waste grain, or picked up in places where grain is left in the shock for a long time. No one will begrudge the birds the corn gathered from the hog lot or about the cattle crib, but when they attack the ripening grain in September it is a different story, and in cases where the birds are so abundant that they take a large part of the crop, it will be difficult to persuade the unfortunate farmer that they did enough good earlier in the season to pay for this loss. There can be no doubt that in many parts of the country these birds are too numerous for the farmer to realize the best results from their services." (Beal.)

Red-winged Blackbird (Agelaius phoniceus).-." In investigating the food habits of the Red-wing over 700 stomachs were examined. These were collected in every month of the year, and show that a little more than $\mathbf{3}$ per cent of the year's food is grain. This is a remarkably small percentage when it is considered that this bird has been the subject of more complaints on the score of grain eating than any other species. In order to understand thoroughly the grain-eating propensities of the Red-iving, a special study of its food for the five months from May to September, inclusive, has been made. Of the stomachs taken in May, 46 per cent contained grain. This percentage falls to $\mathrm{I} I$ in June and then rises in July and culminates in 
August at 72, after which it decreases rapidly. The average for the five months is 46 per cent, that is, in every 100 birds taken 46 have eaten grain. If now we examine the grain-eating record as exhibited by the quantity of that food the results are quite different. In May grain constitutes 2 I per cent of the food by bulk; in June it decreases to 5 per cent; in July it rises to its maximum of 42 per cent; in August it falls off slightly, after which it rapidly decreases and disappears. The average consumption of grain for the five months is 25 per cent of the whole food. Again, if the two months of July and August are considered alone, it is found that out of every Ioo birds 68 have eaten grain, but that the grain constitutes only 40 per cent of the total food for the two months. * * *

"Of the different kinds of cereals, oats is the favorite with the Red-wings, constituting more than half of the grain eaten. Corn stands next in order, and wheat last of all. At the same time many noxious insects and much weed seed are destroyed. The former amounts to over 26 per cent of the year's food, the latter to nearly 57 per cent. Seeds of noxious weeds, eked out by grain found scattered in the fields, form the almost exclusive diet of these birds during the colder months. Even in August, when the destruction of grain is at its height, weed seed forms more than 30 per cent of the food." (Beal.)

Rusty Blackbird (Scolecophagus carolinus)._- "The Rusty Grackle (Scolecophagus carolinus) of the eastern United States and Brewer's Blackbird (S. cyanocephalus) of the west are similar birds, whose habits of associating in large flocks would indicate that they could do great damage to grain fields if they chose to visit them for food. Stomach examinations show that the eastern bird lives to a great extent upon animal substances, principally insects, and as the species retires to the extreme northern edge of the country and beyond to breed, it does not appear in most of the grainraising States until the crops of wheat and oats have been harvested. It feeds to some extent on corn, but the damage appears to be slight. Brewer's Blackbird, on the contrary, breeds over the greater part of its range and only retires from the northern part during a short time in winter. It is more of a grain eater than the Rusty Grackle and does considerable damage in wheat-growing areas in the far west. Like the Rusty Grackle, it is a great consumer of insects." (Beal.)

Cowbird (Malothrus atcr). - This bird is said not to be seriously injurious to grain, but its habit of laying in the nests of smaller and much more valuable species, the young of which are, in consequence, often starved, should be sufficient to warrant us in denying it legal protection.

Bobolink (Dolichony $x$ oryzizorus). - This species furnishes an illustration of a bird which is beneficial in one locality and harmful in another. While with us in 
its breeding season the Bobolink is an undeniably useful bird, feeding on insects and weed seeds, but during its migrations in August and September, when it visits the rice-fields of South Carolina and Georgia, it is quite as undeniably injurious. Admitting that the injury it does in the south is in excess of the good it does in the north, we fear that we are not as yet sufficiently altruistic to destroy this well-loved bird for the benefit of those whom it harms, and for the present, therefore, each State will doubtless deal with its birds without relation to their status in other parts of their range.

Baltimore Oriole : Hangbird (Icterus galbula).-- "Observation both in the field and laboratory shows that caterpillars constitute the largest item of its fare. In II 3 stomachs they formed 34 per cent of the food, and are eaten regularly in varying quantities during all the months in which the bird remains in this country, although fewest are eaten in July, when a little fruit is also taken. The other insects consist of beetles, bugs, ants, wasps, grasshoppers, and some spiders. The beetles are principally click beetles, the larvæ of which are among the most destructive insects known; and the bugs include plant and bark lice, both very harmful, but so small and obscure as to be passed over unnoticed by most birds." (Beal.)

In spite of this good record Orioles are known to do much damage to grapes in the latter part of August by puncturing one or more grapes in a bunch, thereby decreasing their market value. As has been previously suggested, however, the vineyards can be protected from them by the discharge of unshotted guns, and as comparatively few birds of this species remain north of the latitude of New York after the first week in September, it would clearly be undesirable to kill so useful and beautiful a bird when by the exercise of a little vigilance for a comparatively short period the harm it might do may be prevented.

Meadowlarks (Sturnella magna)._- "The Meadowlark is almost wholly beneficial, although a few complaints have been made that it pulls sprouting grain, and one farmer claims that it eats clover seed. As a rule, however, it is looked upon with favor and is not disturbed.

"In the 238 stomachs examined, animal food (practically all insects) constituted 73 per cent of the contents and vegetable matter 27 per cent. As would naturally be supposed, the insects were ground species, such as beetles, bugs, grasshoppers and caterpillars, with a few files, wasps and spiders. A number of the stomachs were taken from birds that had been killed when the ground was covered with snow, but still they contained a large percentage of insects, showing the bird's skill in finding proper food under adverse circumstances.

"Df the various insects eaten, crickets and grasshoppers are the most important, 
constituting 29 per cent of the entire year's food and 69 per cent of the food in August. It is scarcely necessary to enlarge upon this point, but it can readily be seen what an effect a number of these birds must have on a field of grass in the height of the grasshopper season. Of the 238 stomachs collected at all seasons of the year, I78, or more than two-thirds, contained remains of grasshoppers, and one was filled with fragments of 37 of these insects. This seems to show conclusively that grasshoppers are preferred and are eaten whenever they can be procured. The great number taken in August is especially noticeable. This is essentially the grasshopper month, $i$. $e$., the month when grasshoppers reach their maximum abundance; and the stomach examination has shown that a large number of birds resort to this diet in August, no matter what may be the food during the rest of the year.

"Next to grasshoppers, beetles make up the most important item of the Meadowlark's food, amounting to nearly 2 I per cent, of which about one-third are predaceous ground beetles. The others are all harmful species, and when it is considered that the bird feeds exclusively on the ground, it seems remarkable that so ferv useful ground beetles are eaten. Many of them have a disgusting odor, and possibly this may occasionally save them from destruction by birds, especially when other food is abundant. Caterpillars, too, form a very constant element, and in May constitute over 28 per cent of the whole food. May is the month when the dreaded cut worm begins its deadly career, and then the bird does some of its best work. Most of these caterpillars are ground feeders, and are overlooked by birds which habitually frequent trees; but the Meadowlark finds them and devours them by thousands. The remainder of the insect food is made up of a few ants, wasps and spiders, witl a few bugs, including some chinch bugs.

"The vegetable food consists of grain, weed, and other hard seeds ; grain in general amounts to I4, and weed and other seeds to I2 per cent. The grain, principally corn, is mostly eaten in winter and early spring, and must be, therefore, simply waste kernels; only a trifle is consumed in summer and autumn, when it is most plentiful. No trace of sprouting grain was discovered. Clover seed was found in only six stomachs, and but little in each. Seeds of weeds, principally ragweed, barn grass, and smartweed, are eaten from November to April, inclusive, but during the rest of the year are replaced by insects.

"Briefly stated, more than half of the Meadowlark's food consists of harmful insects: its vegetable food is composed either of noxious weeds or waste grain, and the remainder is made up of useful beetles or neutral insects and spiders. A strong point in the bird's favor is that, although naturally an insect eater, it is able to subsist on vegetable food, and, consequently, is not forced to migrate in cold weather 


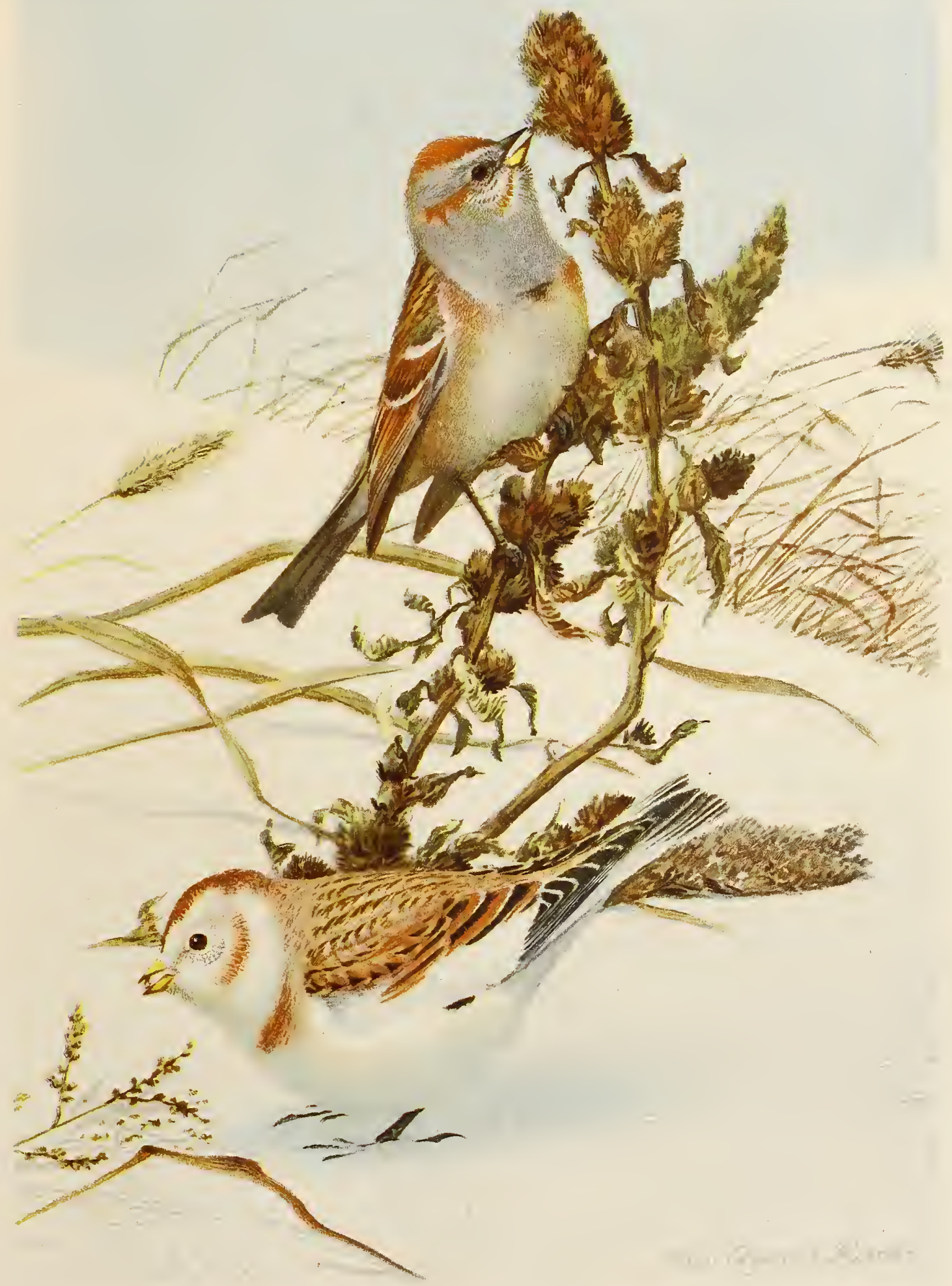

UPPER FIGURE, TREE SPARROW

LOWER FIGURE, SNOWFLAKE

ABOUT $2 / 3$ NATURAL SIZE. 

any farther than is necessary to find ground free from snow. This explains why it remains for the most part in the United States during winter, and moves northward as soon as the snow disappears from its usual haunts.

"There is one danger to which the Meadowlark is exposed. As its flesh is lighly esteemed the birc is often shot for the table, but it is entitled to all possible protection, and to slaughter it for game is the least profitable way to utilize a valuble species." (Beal.)

\section{SPARROWS AND FINCHES. Family Fringillidæ.}

"While Sparrows are noted seed caters, they do not by any means confine themselves to a vegetable diet. During the summer, and especially in the breeding season, they cat many insects, and probably feed their young largely upon the same food. An examination of the stomachs of three species - the Song Sparrow (Mclospiza), Chipping Sparrow (Spizclla socialis), and the Field Sparrow (Spizella pusilla), shows that one-third of the food consists of insects, comprising many injurious beetles, such as snout-beetles or weevils, and leaf-beetles. Many grasshoppers are eaten, and in the case of the Chipping Sparrow these insects form oneeighth of the food. Grasshoppers would seem to be rather large morsels, but the bird probably confines itself to the smaller species: indeed, this is indicated by the fact that the greatest amount (over $36 \%$ ) is eaten in June, when the larger species are still young and the small species most numerous. Besides the insects already mentioned, many wasps and bugs are taken. Predaceous and parasitic hymenoptera and predaceous beetles, all useful insects, are eaten only to a slight extent, so as a whole the Sparrows' insect diet may be considered beneficial.

"Their vegetable food is limited almost exclusively to hard seeds. This might seem to indicate that the birds feed to some extent upon grain, but the stomachs examined show only one kind-oats - and but little of that. The great bulk of the food is made up of grass and weed sced, which form almost the entire diet during the winter, and the amount consumed is immense." (Beal.)

In his important paper on "The Relations of Sparrows to Agriculture," * Dr. Judd remarks: "It is evident that a group of birds so abundant, so widely distributed, and in such constant association with farms and gardens, must play an important part in rural economy, and that a thorough investigation of their food habits should be useful. The results of such an investigation are embodied in the present paper and amply demonstrate the value of these birds to the agriculturist -

*Bull. 15, Div. Biological Survey, U. S. Dept. of Agriculture, Igor, p. 7. 
a value greater than that of any other group of birds whose economic status has thus far been investigated. The native Sparrows contrast markedly in this respect with the introduced English Sparrow, the pernicious habits of which have formed the subject of a special report, and are briefly treated in this bulletin for purpose of comparison (see p. 92). This naturalized Sparrow is a pest wherever it is found, while the native Sparrows are well worthy of protection and encouragement."

Snowflake: Snowbunting (Passcrina nivalis). - " From the examination of the stomachs collected, it would appear that the Snowflake derives fully half its subsistence from two weeds - amaranth and ragweed, and that it does not to any great extent feed on the seeds of crab-grass, pigeon-grass, or other grasses, though it should be stated that McIlwraith reports it as eating the seeds of broom sedge (Andropogon scoparius). Only one per cent of the food contained in the 46 stomachs examined was grass seed. But in addition to the fact that the number of stomachs examined was too small to permit final conclusions to be drawn, for other reasons this should not be taken as showing a distaste for grass seed. The taste for similar food, as shown by the partiality of the birds for grain, and the quantity of grass seed eaten by the closely allied, more southerly ranging Longspurs, indicate that the abstinence of the Snowflake from this food is due to necessity and not choice. We must remember that the grass seed, which falls to the ground when ripe instead of clinging to the stalk, as do many of the seeds of amaranth, lamb's-quarters, and ragweed, is probably buried under the snow during most of the time the Snowflakes are here. The amaranth is tall and its seeds are particularly clinging, and after very heavy snowfalls it is probably the most available food supply the Snowflakes have. Its seeds form half the food found in the stomachs collected in February and March, some of which contained 500 to I,500 each. Such a wholesale destruction of the seeds of this rank weed as is thus indicated is not accomplished by any other bird whose food habits have thus far been investigated. With most species of seed-eating birds amaranth is by no means an important article of diet.

" On account of its work as a good weed destroyer and the apparent absence of any noticeable detrimental food habits, the Snowflake seems to deserve high commendation, and should receive careful protection. Feeding in latitudes that have been deserted by most other weed-destroying birds, these birds render a distinct and most effective service to the northern farmer. And to this should be added that it is their habit, and that of their congeners, the Longspurs, to feed far out in the open plains without regard to the presence of trees or shrubs. In this way they accomplish work that would otherwise be left undone; for most of the other mem- 
bers of the Sparrow family that subsist entirely, or nearly so, on weed seed in the winter will not be found far from convenient shelter to which they can repair in case of danger." (Judd.)

In spite of the great economic value, Snowflakes are killed in great numbers to be sold for food under the name of "Reedbirds." On August 30, I902, 78,000 odd birds of this species were found in cold storage warehouses in New York City, where they were held in defiance of the State law.

Purple Finch (Carpodacus purpureus).- The Purple Finch at certain seasons feeds largely on buds and blossoms and is said to damage fruit trees in this manner. No thorough study of the food habits of the bird appears to have been made, and until our knowledge of its economic status rests on sound basis we may well withhold judgment concerning its economic value. In the meantime we may remember how comparatively few blossoms, under the most favorable conditions, bring forth mature fruit, and consequently how many can be spared without affecting the yield of a tree.

Due consideration should also be given to the fact that the Purple Finch is known to feed on plant lice. (See King.)

American Goldfinch: Thistle Bird (Astragalinus tristis)._- "The Goldfinch, or Wild Canary, is as useful as it is beautiful, and as a weed destroyer has no equals. It confines its attention very largely to one family of plants, the compositx, and it is especially fond of thistles, wild lettuce, wild sunflower, and ragweed. It is so often seen on thistles, both Canada and bull thistles, that it is commonly known as the Thistle bird. Near Washington, D. C., a flock of a dozen birds were seen during the latter part of August feeding on sunflowers that had escaped from cultivation, and in the central and western States the Goldfinches do much good by eating the seeds of wild sunflowers and other closely related weeds. They have also been seen feeding upon wild lettuce (Lactuca spicata), and probably eat prickly lettuce (Lactuca scariola), which has proved the most rapidly spreading weed ever introduced into this country, but as yet no actual observations as to the latter food habit have been made. Stomachs collected in August were filled with seed of compositæ, mostly sunflowers (various species of Helianthus) and thistles (Carduus lanceolatus and other species).

"At Burlington, Iowa, during July and August, Mr. Paul Bartsch found Goldfinches feeding exclusively upon bull thistle (Carduus lanceolatus). He was able to approach within a few feet of several birds while thus engaged, and noticed that the seeds or akenes were bitten off and swallowed, while the plumes or pappus floated away. When there was no wind, the pappus often failed to fly away, and clung to 
the birds, almost burying them with down. A dozen of the birds were killed and their gizzards and gullets were found literally crammed with thistle seeds. At Sing Sing, N. Y., Goldfinches have been seen eating the seeds of the Scotch thistle (Onopordon acanthium) and boneset (Eupatorium perfoliatum). Cone flowers (Rudbeckia hirta), prairie sunflowers (Gaillardia), evening primroses, catnip, elephant's foot (Elephantopus sp.), and mullein also form part of their food, and late in the season they turn their attention to ragweed and consume great quantities of the seeds of this troublesome species. In winter and spring large flocks feed to some extent upon the seeds of conifers and catkin-bearing trees, such as the sycamore and birch. In destroying the seeds of the gray birch (Bctula populifolia) on the edge of the grass lands they do some good, for this tree has a habit of seeding adjacent pastures, which then grow into a thicket of young saplings." (Beal.)

Chipping Sparrow (Spizclla socialis).- Professor Weed writes of a family of Chipping Sparrows, which he watched on June 22, from 3:40 A. M. to 7:50 P. MI.: "During this busy day the parent birds had made almost two hundred visits to the nest, bringing food nearly every time, though some of the trips seemed to be made to furnish grit for the grinding of the food. There was no long interval when they were at work, the longest period between these visits having been twenty-seven minutes. Soft-bodied caterpillars were the most abundant elements of food, but crickets and crane-flies were also seen, and doubtless a great variety of insects were taken."

Tree Sparrow (Spizella monticola).- " Examination of many stomachs shows that in winter the Tree Sparrow feeds entirely upon seeds of weeds; and probably each bird consumes about one-fourth of an ounce a day. In an article contributed to the New York Tribune in I88I the writer estimated the amount of weed seed annually destroyed by these birds in the State of Iowa. Upon the basis of onefourth of an ounce eaten daily by each bird, and supposing that the birds averaged ten to each square mile, and that they remain in their winter range two hundred days, we shall have a total of $1,750,000$ pounds, or 875 tons, of weed seed consumed by this one species in a single season. Large as these figures may scem, they certainly fall far short of the reality. The estimate of ten birds to a square mile is much within the truth, for the Tree Sparrow is certainly more abundant than this in winter in Massachusetts, where the food supply is less than in the western States, and I have known places in Iowa where several thousand could be seen within the space of a few acres. This estimate, moreover, is for a single species, while, as a matter of fact, there are at least half a dozen birds (not all Sparrows) that habitually feed on these seeds during winter." (Beal.) 
Song Sparrow (Mclospiza meloda).- " "Taking the food habits of the Song Sparrow as a whole, it will be readily seen that this bird does much more good than harm and is worthy of protection and encouragement. Only two per cent of the food consists of useful insects, while 18 per cent is composed of injurious insects; and grain, largely waste, amounts to 4 per cent, while the seeds of various species of weeds constitute 50 per cent." (Judd.)

Rose-breasted Grosbeak (Zamelodia ludoviciana).- "When the Colorado potato beetle first swept over the land, and naturalists and farmers were anxious to discover whether or not there were any enemies which would prey upon the pests, the Grosbeak was almost the only bird seen to eat the beetles. Further observation confirmed the fact, and there can be no reasonable doubt that where the bird is abundant it has contributed very much to the abatement of the pest, which has been noted during the last decade. But this is not the only good the bird does, for many other noxious insects besides the potato beetle are also eaten.

"The vegetable food of the Grosbeak consists of buds and blossoms of forest trees and seeds, but the only damage of which it has been accused is the stealing of green peas. The writer has observed it eating peas and has examined the stomachs of several that had been killed in the very act. The stomachs contained a few peas and enough potato beetles, old and young, as well as other harmful insects, to pay for all the peas the birds would be likely to eat in a whole season. The garden where this took place adjoined a small potato field which earlier in the season had been so badly infested with beetles that vines were completely riddled. The Grosbeaks visited the field every day, and finally brought their fledged young. The young birds stood in a row on the topmost rail of a fence and were fed with the beetles which their parents gathered. When a careful inspection was made a few days later, not a beetle, old or young, could be found; the birds had swept them from the field and saved the potatoes." (Beal.)

English Sparrow: House Sparrow (Passer domesticus). -The economic status of the English Sparrow has been more discussed than that of any other bird. There is no doubt, however, that the Sparrow is an undesirable bird. While the grounds for objection to its presence in the city may be limited to its noisiness and filth-producing habits, in the country more serious reasons for condemning it as undesirable can be given. It is not only destructive to fruit and grain, but it occupies feeding places formerly inhabited by native, and, economically, more desirable birds. It does not follow that through pure aggressiveness the Sparrow expels from their homes our Wrens, Bluebirds, Swallows and Martins. The Sparrow's success in replacing these birds is due primarily to its non-migratory habits. Permanently 
resident at or near one place it takes possession of the available nesting sites before our migratory native birds return from the south, and once established the Sparrow is a difficult bird to dislodge. Surprisingly fecund, it begins to breed in March, at the first indication of warm weather, and has been known to rear six broods in a season. At this rate it has been estimated * that should the progeny of one pair of Sparrows all live and breed, at the end of ten years they would amount to 275,7 16,983,698 Sparrows.

The growing use of self-propelling vehicles in our cities increases the seriousness of the Sparrow question. Within a few decades it is probable that comparatively few horses will be used in our larger towns and cities. There has been a decrease of over 8,000 horses, or about I I per cent, in the horse-population of New York City in the past six years.

As the horses diminish in numbers there will be a corresponding diminution in the food supply of the Sparrows. Eventually they will exist in our cities, except in the parks, only in small numbers.

We cannot hope that this loss of food will be followed by the death of what will gradually become the surplus Sparrow population; but, in view of the Sparrow's proved ability to adapt himself to widely-varying conditions, we must believe that when the city fails to yield him a living he will spread into the surrounding country. There he will be brought into direct competition with our native species, with what result it is not difficult to predict.

The extermination of the Sparrow in this country is believed to be an impossibility; but it probably can be kept in check by persistent and continuous effort under the direction of the State; and, in the opinion of the writer, the subject is of sufficient importance to warrant prompt action on the part of the State.

\section{TANAGERS. Family Tanagridæ.}

Scarlet Tanager (Piranga erythromelas).-- "Of twenty-nine specimens examined, one had eaten ants; three, three ichneumon flies, two of them Thalessa lunator?, the other a small species having an extent of wing of one-tenth of an inch; eight, twenty-six caterpillars; three, six diptera, three of them tipulids; seventeen, forty-seven beetles; three, six hemipterous insects; four, seven grasshoppers; one, a small dragon-fly; one, a very large spider; and two, ten harvest-men. Curculios, elaters, and leaf-chaffers, some of them three-fourths of an inch long, were repre-

* The English Sparrow in North America. Bull. I, Div. Economic Ornithology and Mammalogy, U. S. Dept. of Agriculture, p. 29. 


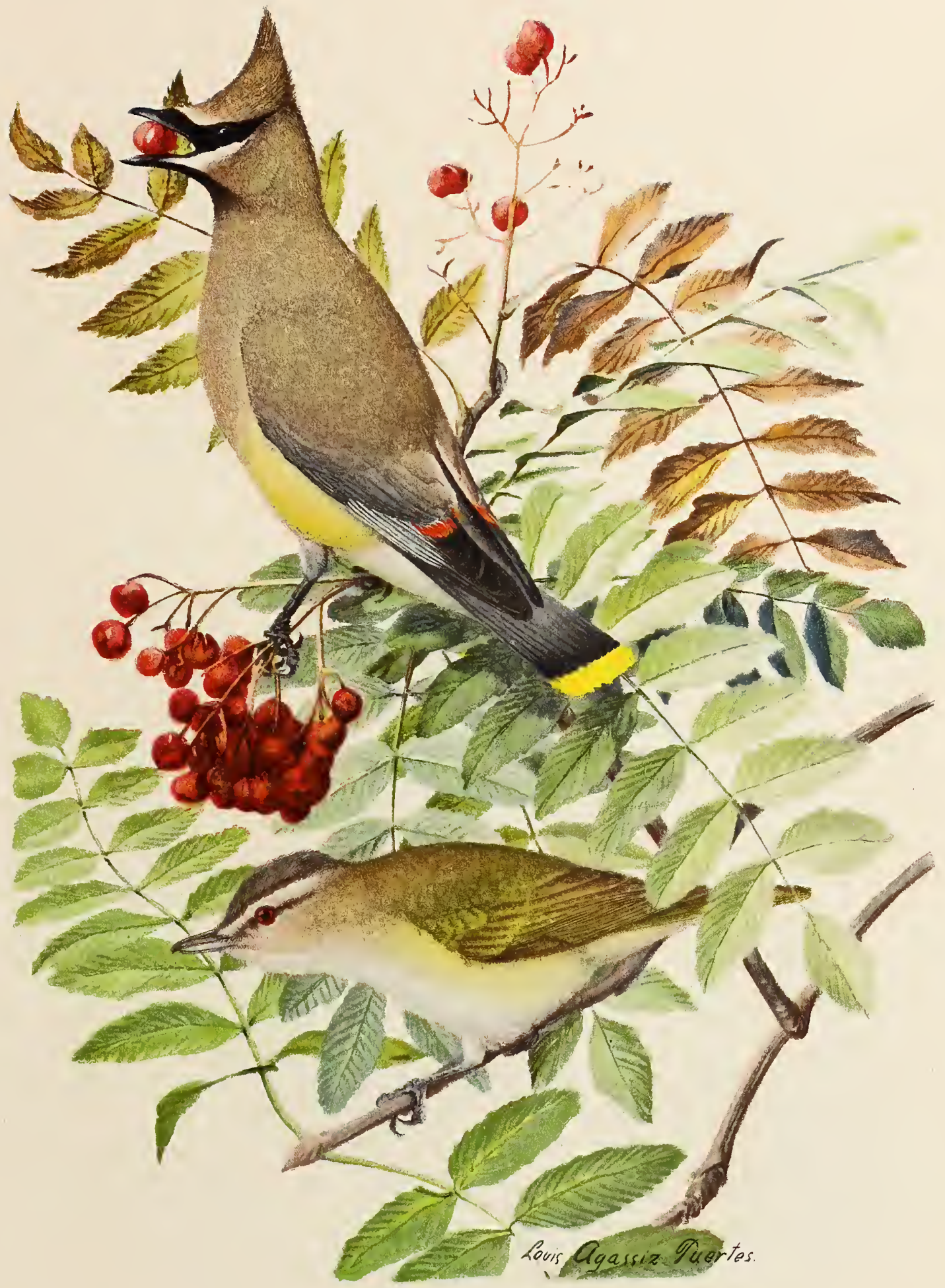

UPPER FIGURE, CEDAR WAXWING

LOWER FIGURE, RED-EYED VIREO

ABOUT $2 / 3$ NATURAL SIZE. 

sented among the beetles. From the stomachs of three young birds less than a week old were taken four caterpillars, one fly, one small grasshopper, one hemipterous insect, together with undetermined fragments." (King.)

\section{SWALLOWS. Family Hirundinidæ.}

"Field observation will convince any ordinarily attentive person that the food of Swallows must consist of small insects captured in mid-air, or perhaps in some cases picked from the tops of tall grass or weeds. This observation is borne out by an examination of stomachs, which shows that the food consists of many small species of beetles which are much on the wing; many species of diptera (mosquitoes and their allies), with large quantities of flying ants and a few insects of similar kinds. Most of them are either injurious or annoying, and the numbers destroyed by Swallows are not only beyond calculation, but almost beyond imagination.

"It is a mistake to tear down the nests of a colony of Cliff Swallows from the eaves of a barn, for, so far from disfiguring a building, the nests make a picturesque addition, and their presence should be encouraged by every device. It is said that Cliff and Barn Swallows can be induced to build their nests in a particular locality, otherwise suitable, by providing a quantity of mud to be used as mortar. Barn Swallows may also be encouraged by cutting a small hole in the gable of the barn, while Martins and White-bellied Swallows will be grateful for boxes, like those for the Bluebird, but placed in some higher situation." (Beal.)

\section{WAXWINGS. Family Ampelidæ.}

Cedar Waxwing : Cherry Bird (Ampelis cedrorum).- "The Cedar Waxwing, or Cherry Bird, inhabits the whole of the United States, but is much less common in the west. Although the great bulk of the species retires southward in winter the bird is occasionally found in every State during the colder months, especially if wild berries are abundant. Its proverbial fondness for cherries has given rise to its popular name, and much complaint has been made on account of the fruit eaten. Observation has shown, however, that its depredations are confined to the trees on which the fruit ripens earliest, while later varieties are comparatively untouched, this probably owing to the fact that when wild fruits ripen they are preferred to cherries, and constitute the bulk of the Cedar Bird's diet.

"In 152 stomachs examined animal matter formed only I 3 and vegetable 87 per cent, showing that the bird is not wholly a fruit eater. With the exception of a 
few snails, all the animal food consists of insects, mainly beetles-and all but one more or less noxious, the famous elm-leaf beetle being among the number. Bark or scale lice were found in several stomachs, while the remainder of the animal food was made up of grasshoppers, bugs and the like. Three nestlings were found to have been fed almost entirely on insects.

"Of the 87 per cent of vegetable food, 74 consisted entirely of wild fruit or seeds and 13 of cultivated fruit, but a large part of the latter was made up of blackberries and raspberries, and it is very doubtiul whether they represent cultivated varieties. Cherry stealing is the chief complaint against this bird, but of the 152 stomachs only 9, all taken in June and July, contained any remains of cultivated cherries, and these aggregate but 5 per cent of the year's food. As 4I stomachs were collected in those months, it is evident that the birds do not live to any great extent on cultivated cherries." (Beal.)

"The Cedar Bird eats caterpillars, spiders, and grasshoppers, but does most good in destroying the elm-leaf beetle that strips our village and city trees of leaves. Mrs. Mary Treat writes of one town in which elms had been ruined for several years before the Cedar Birds came and which were afterward comparatively free from beetles. From one calculation, it is shown that 30 Cedar Birds would destroy 9,000 worms during the month when the cutworm caterpillar is exposed." (Bailey.)

\section{SHRIKES. Family Laniidæ.}

Two species of this family are found in New York. One, the Northern Shrike or Butcherbird, comes in late fall and passes the winter when it feeds largely on small birds. The other, the Loggerhead, comes in the summer and appears to be gradually increasing. It feeds largely on grasshoppers and should be protected.

Butcherbird: Great Northern Shrike (Lanius borealis).-- The Northern Shrike is a predaceous species, preying on insects, meadow mice, and birds. While with us it feeds largely on the two latter, Dr. Judd reporting that during December, January, and February, 55 per cent of its food is birds, while 22 per cent is mammals. In New York State, therefore, it cannot be considered, on the whole, a beneficial species.

Loggerhead Shrike (Lanius ludovicianus).--The Loggerhead is with us during the summer when its food consists largely of grasshoppers. Dr. Judd remarks that the Loggerhead's beneficial qualities outweigh 4 to I its injurious ones. 


\section{VIREOS. Family Vireonidæ.}

Vireos are gleaners, searching the foliage carefully for leaf-eating insects and their eggs; peering beneath the leaves, and examining crevices in the bark for forms of insect-life which are especially injurious. Several of the Vireos are abundant and the service they render is correspondingly important.

Red-eyed Vireo (Vireo olivaceus).-- " From the stomachs of eighteen of this species were taken fifteen caterpillars, five other larvæ; eight beetles - among them five weevils, one longhorn and darkling beetle, seventy heteropterous insects among them sixty-seven chinch-bugs; sixteen winged ants, one ichneumon (?), five dragon-flies, two dipterous insects - one of them Tabanus atratus; and seven dogwood berries. Of thirty-six other specimens examined, fifteen had eaten caterpillars; two other, larvæ; nine beetles - among them two Coccinella mali; three, grasshoppers; two, ants; two, moths; four, insects, none of which were identified; and seven, fruits or seeds, among which were raspberries, dogwood berries, berries of prickly ash and sheep berries." (King.)

Yellow-throated Vireo (Vireo flavifrons).- "Of twenty-one specimens examined, seven had eaten caterpillars - among them geometers; seven beetles - among them weevils and a buprestis; three, grasshoppers; two, moths; two, heteropterous insects - among them leaf-hoppers ; three, dipterous insects." (King.)

Warbling Vireo (Vireo gilvus).- " Of sixteen specimens examined, eight had eaten thirty-four caterpillars; two, five beetles, among which were a lady-bird (Coccinilla G-notata), and a Diabrotica duodecim-punctata; three, three heteropterous insects; two, two crane-flies; one, grasshoppers; two, twenty-eight insects' eggs; and one, dogwood berries." (King.)

\section{WARBLERS. Family Mniotiltidæ.}

With few exceptions the members of this large family, containing many abundant species, feed exclusively upon insects.

Black and White Warbler (Mniotilta varia).— "Owing to the small size of these birds, they find it profitable to feed extensively upon very small insects. For this reason they are able to do a work for which the Nuthatches and Woodpeckers are not so well fitted. It is, therefore, especially desirable that they should attain a greater abundance with us.

"Food: Of seventeen specimens examined, three had eaten five ants; two, twenty-one caterpillars, twenty of which were small measuring-worms; three, four moths; three, five diptera; six, sixteen beetles, one of which was a curculio; two, 
seven heteroptera; one, a caddis-fly; and one a small snail (Physa). Two had eaten one hundred and one insects' eggs, but these, I believe, were contained in the insects which the birds had eaten." (King.)

Redstart (Setophaga ruticilla).--." Its broad-based bill, and strong depending rictals, giving to the mouth, when open, the shape of a wide funnel, its keen vision, and its whole aerial outfit are adjusted to the gall-flies, leaf-miners, and other diminutive insects among which it lives, and upon which, I have no doubt, it feeds. Could it be induced to live in orchards, vineyards, gardens and parks, it would there perform a work which the Pewee, the Least Flycatcher and the Kingbird cannot. Mr. Samuels says he has known a pair to build, and rear a brood, in a garden within five rods from a house.

"Food: From the contents of eleven stomachs, examined collectively, were taken fourteen small beetles, some of them .09 of an inch long; four very small moths, four small hymenopterous insects, one an ichneumon, and one, one of the Proctretrypidx? .I of an inch long; one heteropterous insect .08 of an inch long, and a large number of dipterous insects, the majority of them less than one-terth of an inch long. Three others had in their stomachs a single small larva each." (King.)

\section{PIPITS and WAGTAILS. Family Motacillidæ.}

American Pipits: Titlark (Anthus pensilvanicus).-- No extended study of the food habits of this species appears to have been made. It is asserted, however, by various authors to feed on beetles, spiders, seeds in the fields, and along shore on minute shells, shrimps, etc.

\section{WRENS and THRASHERS. Family Troglodytidæ.}

House Wren (Troglodytes aëdon).- "As regards food habits, the House Wren is entirely beneficial. Practically, he can be said to live upon animal food only, for an examination of 52 stomachs showed that 98 per cent of the stomach contents was made up of insects or their allies, and only 2 per cent was vegetable, including bits of grass and similar matter, evidently taken by accident with the insects. Half of this food consisted of grasshoppers and beetles; the remainder of caterpillars, bugs, and spiders. As the House Wren is a prolific breeder, frequently rearing from twelve to sixteen young in a season, a family of these birds must cause considerable reduction in the number of insects in a garden. Wrens are industrious foragers, searching every tree, shrub, or vine for caterpillars, examining every post and rail of 


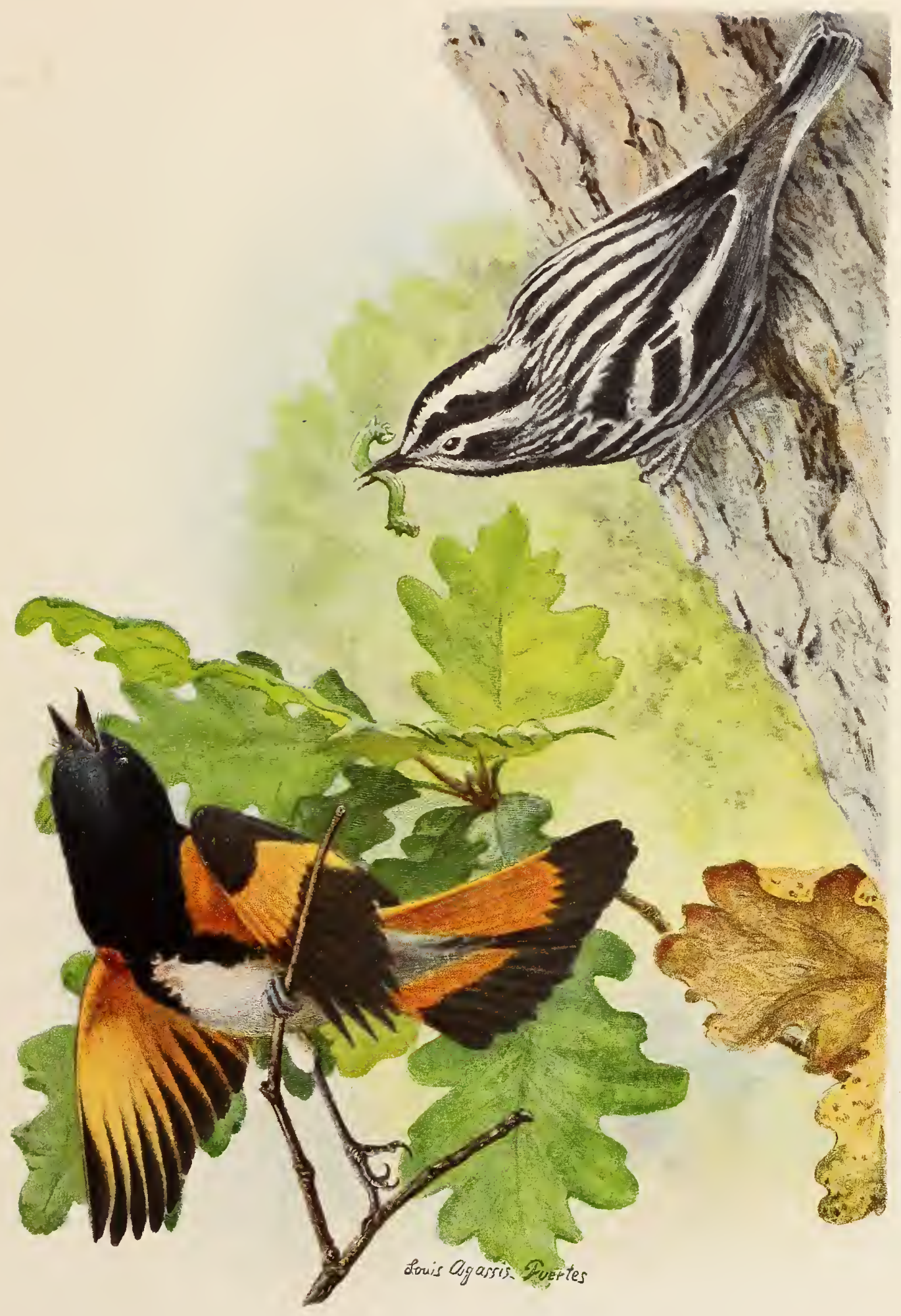

UPPER FIGURE, BLACK AND WHITE WARBLER

LOWER FIGURE, AMERICAN REDSTART

ABOUT NATURAL SIZE. 

the fence, and every cranny in the wall for insects or spiders. They do not as a rule, fly far afield, but work industriously in the immediate vicinity of their nests. In this way they become valuable aids in the garden or orchard, and by providing suitable nesting boxes they may be induced to take up residence where their services will do most good. Their eccentricities in the selection of a home are well known. Almost anything from an old cigar box to a tomato can, an old teapot, a worn boot, or a horse's skull, is acceptable, provided it be placed well up from the ground and out of reach of cats and other prowlers." (Beal.)

Brown Thrasher (Toxostoma rufum).- "The food of the Brown Thrasher consists of both fruit and insects. An examination of I 2 I stomachs showed 36 per cent of vegetable and 64 of animal food, practically all insects, and mostly taken in spring before fruit is ripe. Half the insects were beetles, and the remainder chiefly grasshoppers, caterpillars, bugs, and spiders. A few predaceous beetles were eaten, but, on the whole, its work as an insect destroyer may be considered beneficial.

"Eight per cent of the food is made up of fruits like raspberries and currants which are or may be cultivated, but the raspberries at least are as likely to belong to wild as to cultivated varieties. Grain, made up mostly of scattered kernels of oats and corn, is merely a trifle, amounting to only 3 per cent, and though some of the corn may be taken from newly planted fields, it is amply paid for by the May beetles which are eaten at the same time. The rest of the food consists of wild fruit or seeds. Taken all in all, the Brown Thrasher is a useful bird, and probably does just as good work in its secluded retreats as it would about the garden, for the swamps and groves are no doubt the breeding grounds of many insects that migrate thence to attack the farmers' crops." (Beal.)

Catbird (Galeoscoptes carolinensis).-Professor Beal states that "cultivated fruits can be protected from Catbirds by the simple expedient of planting wild species or others which are preferred by the birds. Some experiments with Catbirds in captivity showed that the Russian mulberry was preferred to any cultivated fruit that could be offered".

He adds: "The stomachs of 213 Catbirds were examined and found to contain 44 per cent of animal (insect) and 56 per cent of vegetable food. Ants, beetles caterpillars, and grasshoppers constitute three-fourths of the animal food, the remainder being made up of bugs, miscellaneous insects and spiders. One-third of the vegetable food consists of cultivated fruits, or those which may be cultivated, such as strawberries, raspberries, and blackberries; but while we debit the bird with the whole of this, it is probable - and in the eastern and well-wooded part of the country almost certain - that a large part was obtained from wild vines. The rest 
of the vegetable matter is mostly wild fruit, such as cherries, dogwood, sour gum, elder berries, greenbrier, spice berries, black alder, sumac, and poison ivy.

"Although the Catbird sometimes does considerable harm by destroying small fruit, the bird cannot be considered injurious. On the contrary, in most parts of the country it does far more good than harm, and the evil it does can be reduced appreciably by the methods already pointed out."

\section{CREEPERS. Family Certhiidæ.}

Brown Creeper (Certhia familiaris).-Probably few birds are more wholly beneficial than this persistent hunter after insects and other eggs. With an apparently never-satisfied hunger for the smaller forms of insect life that live in the crevices of the bark of trees, it searches the tree trunks from daylight until dark, and if the service it renders daily could be expressed in figures we should doubtless find that, individually, the Brown Creeper was among our most valuable birds.

\section{NUTHATCHES AND CHICKADEES. Family Paridæ.}

The members of this family feed largely on the eggs of beetles, plant lice, and other forms injurious to vegetation.

White-breasted Nuthatch (Sitta carolinensis).- "Of thirty-five specimens examined, fourteen had eaten thirty-two beetles — among which were three elaters, one longhorn and a lady-bug (?); one, two ants; one, two caterpillars; one, two grubs of a beetle; one, a spider: one, a chrysalis; one, small toad-stools; five, acorns; and one, corn." (King.)

Chickadee (Parus atricapillus).- The following facts in relation to the food of the Chickadee are taken from Mr. Forbush's study of this species in Massachusetts, previously referred to:

"To determine how many eggs a single Chickadee would eat, a few birds were killed and their stomach contents examined, with surprising results. There was no difficulty in identifying the eggs of the canker-worm moth which were found in the bird's stomach, as a great portion of the shells remained intact. The other insect contents of the stomach were identified for me through the kindness of Mr. A. H. Kirkland, B. Sc., assistant entomologist of the State Board of Agriculture, who made the examinations. Although it was impossible in all cases to learn with certainty the species to which certain insects belonged, it was evident they belonged to genera known to be of injurious habits.

"I take the following from Mr. Bailey's notes: 


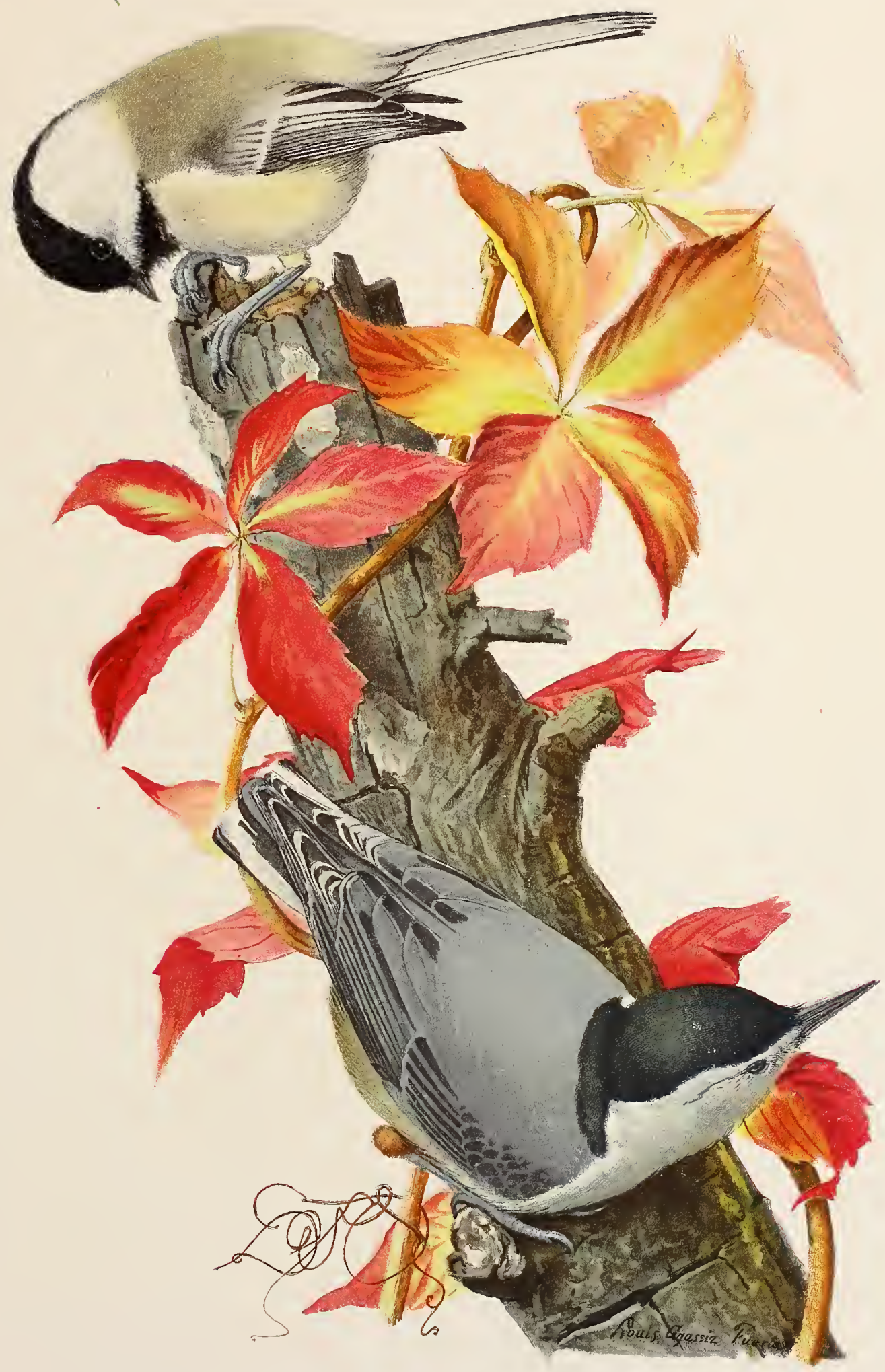

UPPER FIGURE, CHICKADEE (PARUs AtricapilluUs)

LOWER FIGURE, WHITE-BREASTED NUTHATCH (SITTA CAROLINENSIS) ABOUT 5/6 NATURAL SIZE. 

"Number of Eggs of the Fall Canker-worm Found in the Stomachs of Chickadees.

EGGS

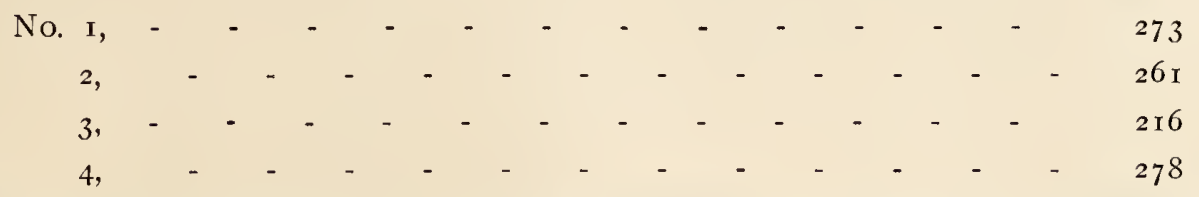

making in all 1,028 eggs found in the stomachs of four birds. Four birds killed later in the season had eaten the female imagos of the spring canker-worm (Paleacrita vernata), as follows:

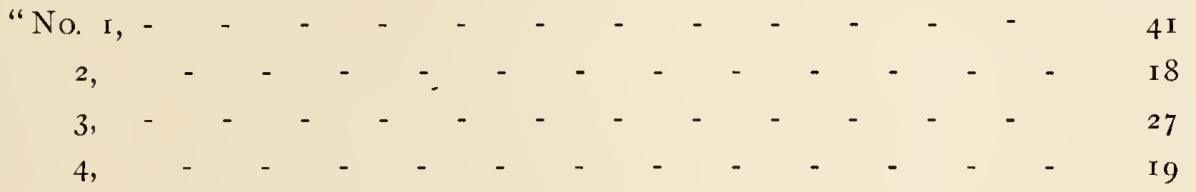

making a total of 105. In Nos. 2, 3 and 4 of the last table there were a large number of eggs also. It is safe to say that there were 150 eggs in each stomach, in addition to the female moths eaten.

"Mr. Bailey carefully counted the eggs in the ovaries of twenty of these female moths, with the following result:

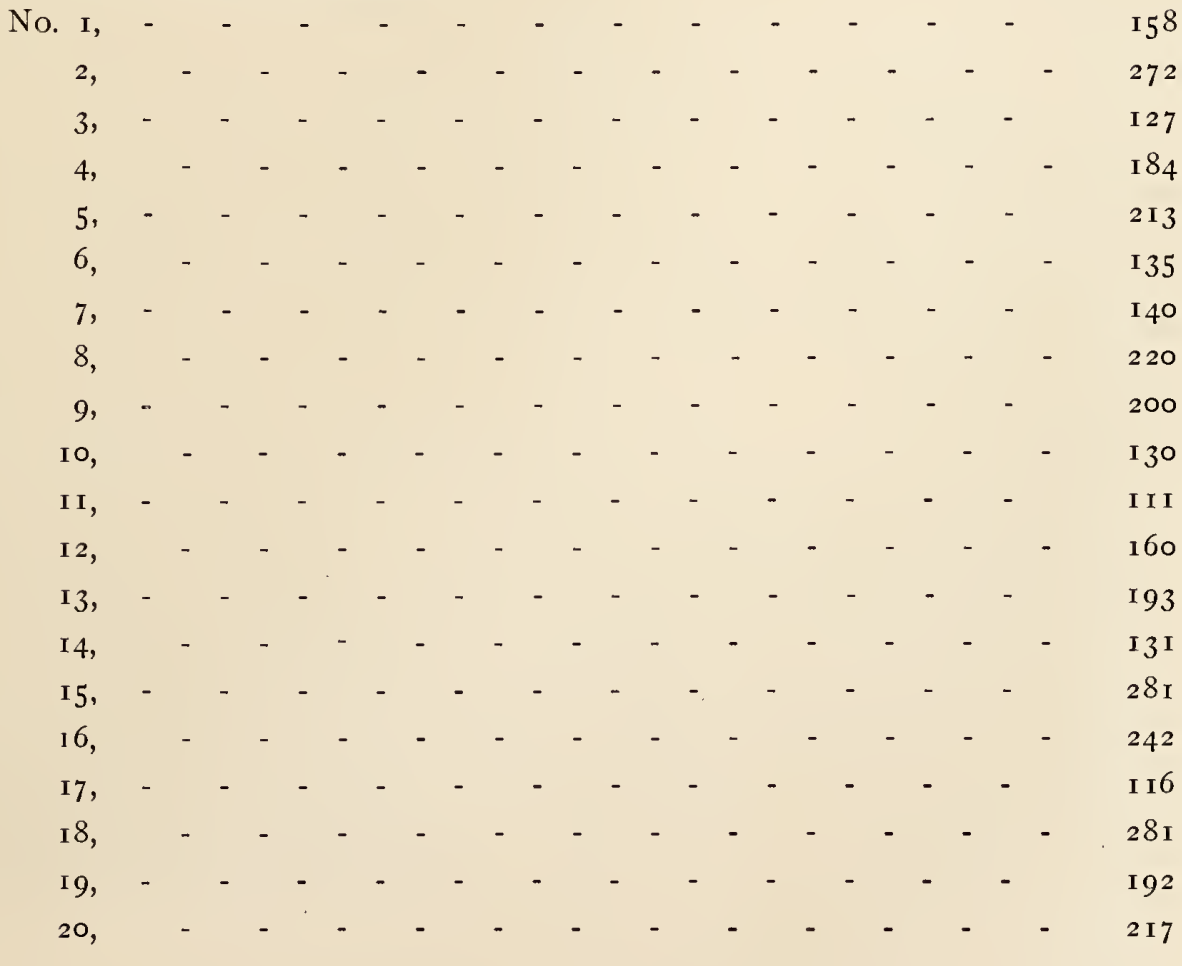


"It will be seen from this table that the average number of eggs found in each moth is I85. Mr. Bailey is very positive, from his continuous field observations, that each Chickadee will devour on the average 30 female canker-worm moths per day from the 2oth of March until the I5th of April, provided these insects are plentiful. If the average number of eggs laid by each female is I85, one Chickadee would thus destroy in one day 5,550 eggs; and in the twenty-five days the canker-worm moths 'run' or crawl up the trees, I38,750. It may be thought that this computation is excessive, and it is probable that some of the moths were not captured until they had laid some of their eggs, but the Chickadees are also busy eating these eggs. * * * When we consider further that 4I of these insects, distended as they were with eggs, were found at one time in the stomach of one Chickadee, and that the digestion of the bird is so rapid that its stomach was probably filled several times daily, the estimate made by Mr. Bailey seems a very conservative one. He now regards the Chickadee as the best friend the farmer has, for the reason that it is with him all the year, and there is no bird that can compare with it in destroying the female moths and their eggs." (Forbush.)

\section{KINGLETS, GNATCATCHERS, ETC. Family Sylviidæ.}

The small size of Kinglets combined with their great activity permits them to explore the terminal buds more easily than larger birds could, and they therefore occupy an important position in the army of bird tree protectors.

Rusty-crowned Kinglet (Regulus calendula)._- "Of seven specimens examined, two had eaten four small caterpillars; three, five beetles; one, an ant; one, a chalcis-fly, and two bits of insects not identified." (King.)

Golden-crowned Kinglet (Regulus satrapa)._- "Of nine specimens examined two had eaten twelve small diptera; three, nine small beetles; one, four caterpillars; one, a small chrysalis, and three, very small bits of insects, too fine to be identified." (King.)

\section{THRUSHES, BLUEBIRDS, ETC. Family Turdidæ.}

Robin (Merula migratoria).- "The Robin builds its nest in orchards and gardens, and occasionally takes advantage of a nook about the house, or under the shelter of the roof of a shed or outbuilding. Its food habits have sometimes caused apprehension to the fruit grower, for it is fond of cherries and other small fruits, particularly the earlier varieties. For this reason many complaints have been lodged against it, and some persons have gone so far as to condemn the bird. The 


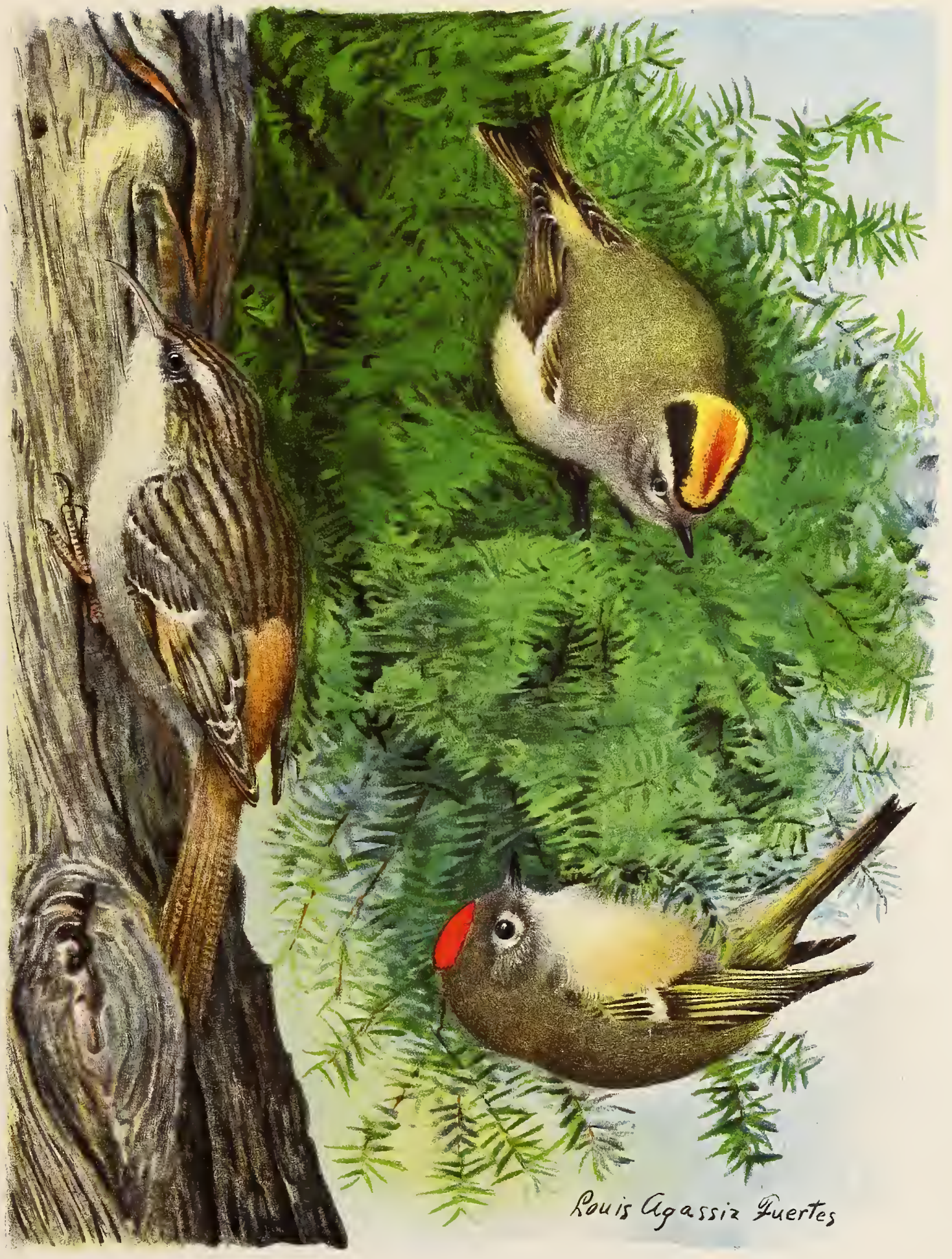

UPPER FIGURE, GOLDEN-CROWNED KINGLET LOWER FIGURE, RUBY-CROWNED KINGLET LEFT-HAND FIGURE, BROWN CREEPER 

Robin is, however, too valuable to be exterminated, and choice fruit can be readily protected from its depredations.

"An examination of 330 stomachs shows that over 42 per cent of its food is animal matter, principally insects, while the remainder is made up largely of small fruits or berries. Over 19 per cent consists of beetles, about one-third of which are useful ground beetles, taken mostly in spring and fall, when other insects are scarce. Grasshoppers make up about one-tenth of the whole food, but in August comprise over 30 per cent. Caterpillars form 6 per cent, while the rest of the animal food, about 7 per cent, is made up of various insects, with a few spiders, snails, and angle-worms. All the grasshoppers, caterpillars, and bugs, with a large 'portion of the beetles, are injurious, and it is safe to say that noxious insects comprise more than one-third of the Robin's food.

"Vegetable food forms nearly 58 per cent of the stomach contents, over 47 being wild fruits, and only little more than 4 per cent being possibly cultivated varieties. Cultivated fruit amounting to about 25 per cent was found in the stomachs in June and July, but only a trifle in August. Wild fruit, on the contrary, is eaten every month, and constitutes a staple food during half the year. No less than forty-one species were identified in the stomachs; of these, the most important were four species of dogwood, three of wild cherries, three of wild grapes, four of greenbrier, two of holly, two of elder; and cranberries, huckleberries, blueberries, barberries, service berries, hackberries, and persimmons, with four species of sumac, and various other seeds not strictly fruit.

"The depredations of the Robin seem to be confined to the smaller and earlier fruits, and few, if any, complaints have been made against it on the score of eating apples, peaches, pears, grapes, or even late cherries. By the time these are ripe the forests and hedges are teeming with wild fruits, which the bird evidently finds more to its taste. The cherry, unfortunately, ripens so early that it is almost the only fruit accessible at a time when the bird's appetite has been sharpened by a longcontinued diet of insects, earth-worms, and dried berries, and it is no wonder that at first the rich juicy morsels are greedily eaten. In view of the fact that the Robin takes ten times as much wild fruit as cultivated fruit, it seems unwise to destroy the birds to save so little. Nor is this necessary, for by a little care both may be preserved. Where much fruit is grown it is no great loss to give up one tree to the birds; and in some cases the crop can be protected by scarecrows. Where wild fruit is not abundant, a few fruit-bearing shrubs and vines judiciously planted will serve for an ornament and provide food for the birds. The Russian mulberry is a vigorous grower and a profuse bearer, ripening at the same time as the cherry, and, 
so far as observation has gone, most birds seem to prefer its fruit to any other. It is believed that a number of these planted around the garden or orchard would fully protect the more valuable fruits." (Beal.)

Wood Thrush (Hylocichla mustelina).- Professor Forbes writes after examining the contents of twenty-two birds of this species: "Seventy-one per cent of their food consisted of insects and twenty per cent of fruit, a small ratio of spiders and mollusks, and an unusually large percentage of Myriopoda making up the remainder." After discussing in detail the bird's economic relations the same author adds : "Its advances, therefore, are to be cordially encouraged by the gardener and farmer - a fact which must be especially agreeable to every lover of bird music, who has learned to recognize the full, clear, rich, exquisite strains of this songster."

Hermit Thrush (Hylocichla guttata pallasii).- Of the food contents of the stomachs of twenty-one Hermit Thrushes Professor Forbes writes: "Eighty-four per cent of the food consisted of insects, four per cent of spiders, and twelve per cent of thousand-legs. Ants amounted to fifteen per cent, Lepidoptera to nineteen per cent, including a few Phalænidæ, and Diptera only to three - chiefly the larvæ of Bibio. Coleoptera make thirty per cent of the carabidx."

Bluebird (Sialia sialis).- "So far as known, this bird has not been accused of stealing fruit or of preying upon any crops. An examination of 205 stomachs showed that 76 per cent of the food consists of insects and their allies, while the other 24 per cent is made up of various vegetable substances, found mostly in stomachs taken in winter. Beetles constitute 28 per cent of the whole food, grasshoppers 22, caterpillars II, and various insects, including quite a number of spiders, comprise the remainder of insect diet. All are more or less harmful, except a few predaceous beetles, which amount to 8 per cent, but in view of the large consumption of grasshoppers and caterpillars, we can at least condone this defence, if such it may be called. The destruction of grasshoppers is very noticeable in the months of August and September, when these insects form more than 60 per cent of the diet.

"It is evident that in the selection of its food the Bluebird is governed by abundance rather than by choice. Predaceous beetles are eaten in spring, as they are among the first insects to appear; but in early summer caterpillars form an important part of the diet, and are replaced a little later by grasshoppers. Beetles are eaten at all times, except when grasshoppers are more easily obtained.

"So far as its vegetable food is concerned, the Bluebird is positively harmless. The only trace of any useful product in the stomachs consisted of a few blackberry seeds, and even these more probably belonged to wild than cultivated varieties. Following is a list of the various seeds which were found: Blackberry, chokeberry, 


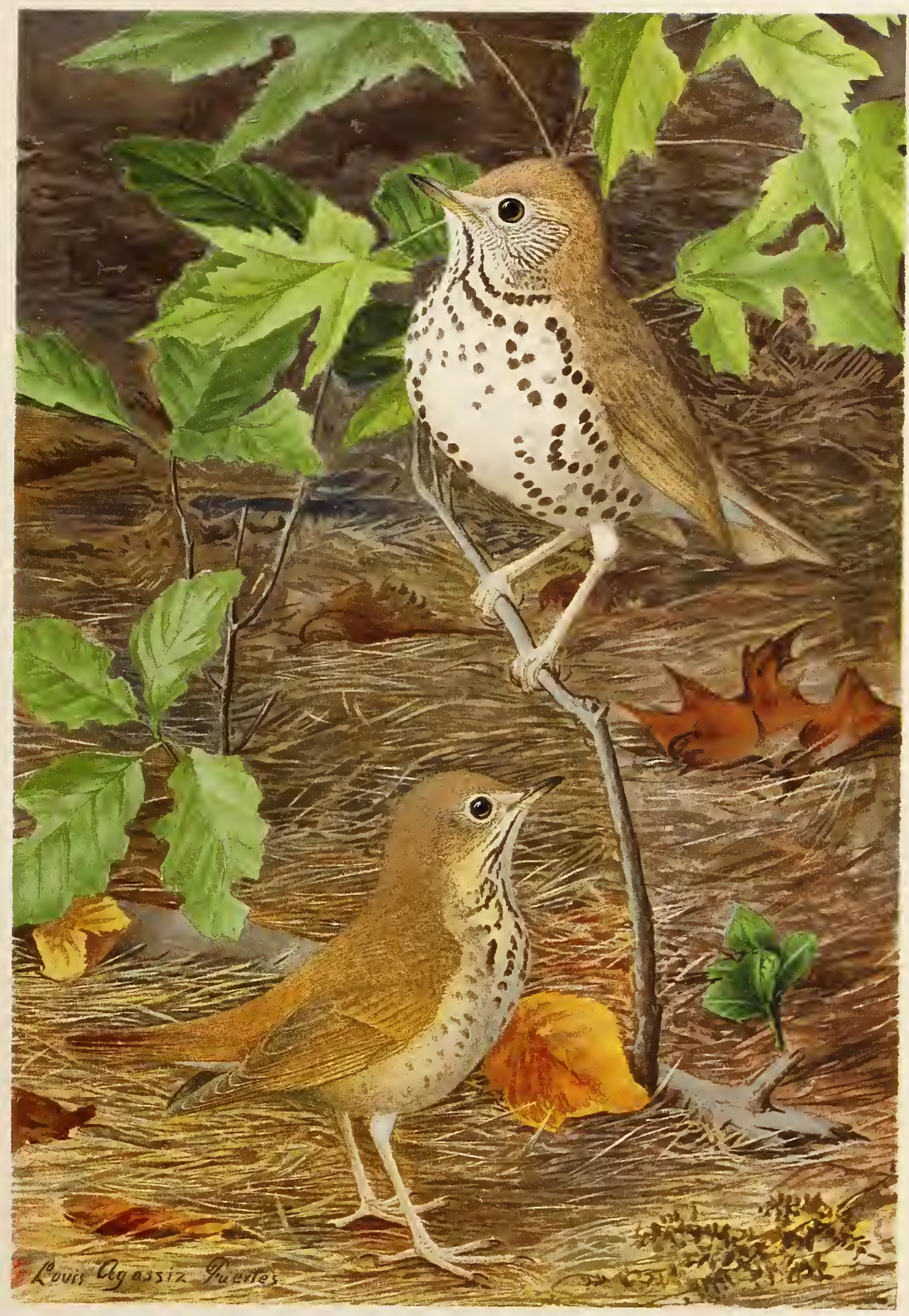

UPPER FIGURE, WOOD THRUSH

LOWER FIGURE, HERMIT THRUSH

ABOUT 2/3 NATURAL SIZE. 

juniperberry, pokeberry, partridge berry, greenbrier, Virginia creeper, bittersweet, holly-strawberry bush, false spikenard, wild sarsaparilla, sumac (several species), rose haws, sorrel, ragweed, grass, and asparagus. This list shows how little the Bluebird depends upon the farm or garden to supply its needs, and indicates that by encouraging the growth of some of these plants, many of which are highly ornamental, the bird can be i ıduced to make its home on the premises." (Beal.)

\section{A List of the More Important Papers Relating to the Food of American Birds.}

I859. Jenks, J. W. P., Trans. Mass. Hort. Soc.

I 859. Treadwell, D., [Food of Young Robins.] Proc. Bost. Soc. Nat. Hist., VI, pp. 396-399.

1878. Aughey, Samuel, Notes on the Nature of the Food of the Birds of Nebraska.

I880. Forbes, S. A., The Food of Birds. Bull. 3, Ills. State Laboratory of Nat. Hist., pp. 80-149. Trans. Ills. Hort. Soc., XIII, pp. I20-I72.

I883. King, F. H., Economic Relations of Wisconsin Birds. Geology of Wisconsin, Vol. I, pp. 44I-6Io.

I883. Forbes, S. A., The Regulative Action of Birds upon Insect Oscillations. Bull. 6, Ills. State Laboratory of Nat. Hist., pp. 3-32.

1886. Merriam, C. Hart, Report of Ornithologist and Mammalogist. Report of U. S. Commissioner of Agriculture, pp. 227-258.

1887. Merriam, C. Hart, Report of Ornithologist and Mammalogist. Report of U.S. Commissioner of Agriculture, pp. 399-456.

I887. Fisher, A. K., Food for Hawks and Owls. Report of U. S. Commissioner of Agriculture, pp. 402-422.

1887. Fisher, A. K., Experiments in Poisoning. Ibid., pp. 423-426.

1887. Bailey, Vernon, Reports on Some of the Results of a Trip Through Parts of Minnesota and Dakota. Ibid., pp. 426-454.

1887. Fisher, A. K., Notes on the Depredations of Blackbirds and Gophers in Northern Iowa and Southern Minnesota in the Fall of I887. Ibid., pp. $454-456$.

1888. Merriam, C. Hart, Report of the Ornithologist and Mammalogist. Report of the Commissioner of Agriculture, pp. 477-536.

I888. Fisher, A. K., The Sparrow Hawk (Falco sparverius). Ibid., pp. 49I-496.

I888. Fisher, A. K., The Short-Eared Owl (Asio accipitrinus). Ibid., pp. 496-498.

I888. Barrows, Walter B., The Food of Crows. Ibid., pp. 498-535. 
I888. Warren, B. H., Report on the Birds of Pennsylvania, with Special Reference to the Food Habits, Based on over Three Thousand Stomach Examinations. Harrisburg, Pa. E. K. Meyer, State Printer, pp. xii-260; colored pll., 50.

1889. Barrows, Walter B., The English Sparrow in North America, Especially in its Relation to Agriculture. Bull. No. I, Div. of Economic Ornithology and Mammalogy, U. S. Dept. of Agriculture, pp. i-405, I map.

1889. Merriam, C. Hart, Report of the Ornithologist and Mammalogist. First Report of the Secretary of Agriculture, pp. $36_{3}-376$.

1889. Fisher, A. K., Marsh Hawks (Circus lutdsonius). Ibid., pp. 370-372.

1889. Fisher, A. K., Common Screech Owl (Megascops asio). Ibid., pp. 372-376.

I 890. Merriam, C. Hart, Report of the Ornithologist and Mammalogist. Report of the Secretary of Agriculture, pp. 277-285.

1890. Barrows, Walter B., Seed Planting by Birds. Ibid., pp. 280-285.

I890. Merriam, C. Hart, Birds which Feed on Mulberries. Ibid., p. 285.

I890. Warren, B. H., Report on the Birds of Pennsylvania, with Special Reference to the Food Habits, Based on over Four Thousand Stomach Examinations. Second edition. Harrisburg, Pa. E. K. Meyer, State Printer, pp. xiv434 ; pll., 100.

I89I. Merriam, C. Hart, Report of the Ornithologist and Mammalogist. Report of the Secretary of Agriculture, pp. 267-27I.

I892. Merriam, C. Hart, Report of the Ornithologist and Mammalogist. Report of the Secretary of Agriculture, pp. I8I-200.

I892. Barrows, Walter B., Food of the Horned Larks or Shore Larks (Otocoris). Ibid., pp. 193-197.

1892. Beal, F. E. L., Food Habits of the Cedar Bird (Ampelis cedrorum). Ibid., pp. 197-200.

1893. Fisher, A. K., The Hawks and Owls of the United States in their Relation to Agriculture. Bull. No. 3, Div. of Ornithology and Mammalogy, U. S. Dept. of Agriculture, pp. 209; colored pll., 26.

1893. Merriam, C. Hart, Report of the Ornithologist and Mammalogist. Report of the Secretary of Agriculture, pp. 227-234.

1893. Barrows, Walter B., Food Habits of the Kingbird or Bee Martin (Tyrannus tyranmus). Ibid., pp. 233, 234 .

I894. Merriam, C. Hart, The Geographic Distribution of Animals and Plants in North America. Yearbook of the U. S. Dept. of Agriculture, pp. 203-2I4. I 894. Fisher, A. K., Hawks and Owls as Related to the Farmer. Ibid., pp. 2 I 5-232. 1894. Beal, F. E. L., The Crow Blackbirds and their Food. Ibid., pp. 233-248. 
1895. Barrows, Walter B., and Schwarz, E. A., The Common Crow of the United States. Bull. No. 6, Div. of Ornithology and Mammalogy, U. S. Dept. of Agriculture, pp. I-98.

1895. Beal, F. E. L., Preliminary Report on the Food of Woodpeckers. Bull. No. 7, U. S. Dept. of Agriculture, pp. I-39.

I 895. Forbush, E. H., Birds as Protectors of Orchards. Bull, No. 3, Series of i895, Mass. Board of Agriculture, pp. 20-32.

I895. Judd, Sylvester D., Four Common Birds of the Farm and Garden. Yearbook of the U. S. Dept. of Agriculture, pp. 405-418.

I895. Beal, F. E. L., The Meadowlark and Baltimore Oriole. Ibid., pp. 419-430.

1896. Fisher, A. K., Food of the Barn Owl (Strix pratincola). Science, III, pp. 623,624 .

ı896. Forbush, E. H., The Crow in Massachusetts. Bull. No. 4, Series of i896, Mass. Board of Agriculture, pp. 24-40.

I896. Palmer, T. S., Extermination of Noxious Animals by Bounties. Yearbook U. S. Dept. of Agriculture, pp. 55-68.

I896. Beal, F. E. L., The Blue Jay and its Food. Ibid., pp. 197-206.

I896. Merriam, Florence A., How Birds Affect the Farm and Garden. Forest and Stream, I896; also printed separately, 16 mo., pp. 32.

1897. Beal, F. E. L., Some Common Birds in their Relation to Agriculture. Farmers' Bull. No. 54, U. S. Dept. of Agriculture, pp. I-4O.

I897. Merriam, C. H., Chief, Biological Survey [Report of Work of]. Yearbook U. S. Dept. of Agriculture, pp. I I 5-122.

I 897. Beal, F. E. L., Birds that Injure Grain. Ibid., pp. 345-350.

I897. Judd, Sylvester D., Methods in Economic Ornithology, with Special Reference to the Catbird. Am. Naturalist, pp. 392-397.

I8g8. Palmer, T. S., The Danger of Introducing Noxious Animals and Birds. Yearbook U. S. Dept. of Agriculture, pp. 87-I Io.

I 898. Judd, Sylvester D., Birds as Weed Destroyers. Ibid., pp. 22I-232.

I898. Weed, Clarence M., The Feeding Habits of the Chipping Sparrow. Bull. 55, New Hampshire College Agricultural Experiment Station, pp. IOI-I IO.

I898. Weed, Clarence M., The Winter Food of the Chickadee. Ibid., Bull. 54, pp. $85-98$.

1898. Rhoads, S. N., "Noxious" or "Beneficial"? False Premises in Economic Zoology. Am. Naturalist, pp. 571-581.

I 898. Forbush, E. H., Nature's Foresters. Bull. No. I, Series of I898, Mass. Board of Agriculture, pp. 27-40.

I898. Beal, F. E. L., The Food of Cuckoos. Bull. No. 9, Div. Biological Survey. U. S. Dept. of Agriculture, pp. 7-I4. 
I 898. Judd, Sylvester D., The Food of Shrikes. Ibid., pp. I 5-26.

I898. Merriam, Florence A., Birds of Village and Field. A Bird Book for Beginners. Houghton, Mifflin \& Co. Contains much information regarding food of birds.

I898. Nash, Charles W., The Birds of Ontario in Relation to Agriculture. Reprinted from the Report of the Farmers' Institutes of Ontario by the Ontario Dept. of Agriculture, Toronto, pp. I-32.

I899. Palmer, T. S., A Review of Economic Ornithology in the United States. Yearbook of the U. S. Dept. of Agriculture, pp. 259-292.

I 899. Beal, F. E. L., Economic Relations of Birds and their Food. Proc. Twentyfourth Annual Meeting of the N. J. State Hort. Soc., pp. I-27.

1899. Grant, Annie M., Birds. Report R. I. Board of Agriculture for i899, pp. 33.

I 899. Montgomery, Thomas H., Jr., Observations on Owls, with Particular Regard to their Feeding Habits. Am. Naturalist, pp. 563-572.

I 899. Praeger, Wm. E., Birds in Horticulture. A paper read before the State Horticultural Society at Springfield, Ills., Dec. 26, I899, pp. I-I2.

I9oo. Beal, F. E. L., How Birds Affect the Orchard. Yearbook U. S. Dept. of Agriculture, pp. 29I-304.

1900. Judd, Sylvester D., The Food of Nestling Birds. Ibid., pp. 4I I-436.

190o. Chapman, Frank M.. The Value of the Bird to the Commonwealth. Report of the Secretary of the State Board of Agriculture of Connecticut, pp. $4 \mathrm{I}$.

I90I. Brown, John P., The Relation of Birds and Forests. A paper read before the Audubon Society of Indiana at Indianapolis, March I9, I90I, pp. 3.

I90I. Bruner, Lawrence, Birds in their Relation to Agriculture. Proc. Neb. Ornithologists' Union (Lincoln, Neb.), pp. i 8-29.

I901. Judd, Sylvester D., The Relation of Sparrows to Agriculture. Bull. No. I5, Div. Biological Survey, U. S. Dept. of Agriculture, pp. I-98.

I90I. Weed, Clarence M., and Dearborn, Ned, The Food of the Myrtle Warbler.

I902. Attwater, H. P., The Relation of Birds to the Farmer. An address delivered at the Annual Session of the Texas Farmers' College Station, Texas, July I 7 , I902, pp. I-I 2 .

1902. Bailey, Florence Merriam, Handbook of Birds of the Western United States. Houghton, Mifflin \& Co. Contains much concerning the food of birds.

I902. Judd, S. D., The Birds of a Maryland Farm. Bull. I7, Biological Survey, U. S. Dept. of Agriculture.

1902. IVeed, Clarence Moores, The Mission of the Birds. Nature Study Leaflet No. 2, N. H. College Agricultural Experiment Station, pp. I5-24.

1902. Weed, Clarence M., A Partial Bibliography of the Economic Relations of North American Birds. Ibid., Technical Bull. No. 3, pp. I37-179. 





LIBRARY OF CONGRESS

|||||||||||||||||"||||||||||||||||||

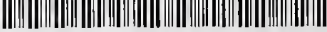

0001733403 ?

0 